\title{
Amphibians and reptiles from the Parque Nacional da Tijuca, Brazil, one of the world's largest urban forests
}

\author{
Thiago Arnt Dorigo ${ }^{1}$, Carla Costa Siqueira ${ }^{\left({ }^{D}\right.}{ }_{*}$, Jane C. F. Oliveira ${ }^{(\mathbb{D})}$, Luciana Ardenghi Fusinatto ${ }^{(\mathbb{D})}$, \\ Manuela Santos-Pereira $^{1}{ }^{(D)}$, Marlon Almeida-Santos ${ }^{1}$ (D), Thiago Maia-Carneiro ${ }^{1,2}{ }^{(D)}$, Caroline N. C. Reis ${ }^{1} \&$ \\ Carlos Frederico Duarte Rocha ${ }^{1}$ iD \\ ${ }^{1}$ Universidade do Estado do Rio de Janeiro, Instituto de Biologia Roberto de Alcantara Gomes, Departamento \\ de Ecologia, Rua São Francisco Xavier 524, Maracanã, 20550-019, Rio de Janeiro, RJ, Brasil \\ ${ }^{2}$ Universidade de São Paulo, Instituto de Biociências, Departamento de Fisiologia, São Paulo, SP, Brasil. \\ *Corresponding author: carlacsiqueira@yahoo.com.br
}

DORIGO, T.A., SIQUEIRA, C.C., OLIVEIRA, J.C.F., FUSINATTO, L.A., SANTOS-PEREIRA, M., ALMEIDASANTOS, M., MAIA-CARNEIRO, T., REIS, C.N.C., ROCHA, C.F.D. Amphibians and reptiles from the Parque Nacional da Tijuca, Brazil, one of the world's largest urban forests. Biota Neotropica 21(2): e20200978. https://doi.org/10.1590/1676-0611-BN-2020-0978.

\begin{abstract}
The Parque Nacional da Tijuca in Rio de Janeiro, Brazil, is considered to be one of the world's largest urban forests, however no systematic inventory of its herpetofauna is available. In the present study, we surveyed the amphibians and reptiles of this park to assess its species composition (including secondary data) and obtain estimates of species richness and abundance. We conducted active searches (460 hours) between January 2013 and December 2015. We identified the taxa endemic to either the Atlantic Forest or Rio de Janeiro state, and verified the conservation status of each species in the international, Brazilian, and state red lists. We also estimated the species richness and sampling sufficiency by rarefaction curves and Bootstrap richness estimator, and analyzed the distribution of the species abundance in Whittaker plots. We recorded 3,288 individuals over 36 months, representing 24 species of amphibians and 25 reptiles. The cumulative species curves, rarefaction, and the richness estimated indicated that sampling effort was adequate. Species abundance adjusted to the log-series model in both amphibians and reptiles. The four most abundant amphibians represented $70 \%$ of the individuals recorded in this group, while the two most abundant reptiles represented $60 \%$ of the total individuals. The inclusion of the secondary data raised the number of amphibian species to 38 , and the number of reptiles to 36 . Approximately $80 \%$ of the amphibian species and $28 \%$ of the reptile species recorded are endemic to the Atlantic Forest, and six of the amphibian species are endemic to Rio de Janeiro state. Six amphibian species and one reptile species are classified under some threat of extinction, and two reptile species were exotic. The considerable diversity of the herpetofauna of the Parque Nacional da Tijuca, which includes endemic and threatened species, reflects the effectiveness of the reforestation of this protected area and emphasizes the importance of its conservation.
\end{abstract}

Keywords: Atlantic Rainforest; Conservation; Endemism; Herpetofauna; Inventory.

\section{Anfíbios e répteis do Parque Nacional da Tijuca, Brasil, uma das maiores florestas urbanas do mundo}

Resumo: O Parque Nacional da Tijuca, no Rio de Janeiro, Brasil, é considerado uma das maiores florestas urbanas do mundo, no entanto nenhum inventário sistemático de sua herpetofauna está disponível. No presente estudo, pesquisamos os anfíbios e répteis deste parque para acessar sua composição de espécies (incluindo dados secundários) e obter estimativas da riqueza e da abundância de espécies. Realizamos buscas ativas ( 460 horas) entre janeiro de 2013 e dezembro de 2015 . Identificamos os taxa endêmicos da Mata Atlântica ou do estado do Rio de Janeiro, e verificamos o status de conservação de cada espécie nas listas vermelhas internacional, brasileira e estadual. Também estimamos a riqueza de espécies e a suficiência amostral através de curvas de rarefação e do estimador de riqueza Bootstrap, e analisamos a distribuição de abundância das espécies através de plots de Whittaker. Registramos 3.288 indivíduos ao longo dos 36 meses, representando 24 espécies de anfíbios e 25 de répteis. As curvas cumulativas de espécies, a rarefação, e a riqueza estimada indicaram que o esforço amostral foi adequado. A abundância das espécies se ajustou ao modelo de série logarítmica tanto para os anfíbios como para os répteis. As quatro espécies de anfíbios mais abundantes representaram $70 \%$ dos indivíduos registrados neste grupo, enquanto as duas espécies de répteis mais abundantes representaram $60 \%$ do total de indivíduos. A inclusão dos dados secundários elevou o número de espécies de anfíbios para 38 e o de répteis para 36 . Aproximadamente $80 \%$ dos anfíbios e $28 \%$ dos répteis registrados são endêmicos da Mata Atlântica e seis espécies de anfíbios são endêmicos do estado do Rio de Janeiro. Seis espécies de anfíbios e uma de réptil estão classificadas sob alguma ameaça de extinção, e dois répteis constituem espécies exóticas. A considerável diversidade da herpetofauna do Parque Nacional da Tijuca, que inclui espécies endêmicas e ameaçadas, reflete a efetividade do reflorestamento dessa área protegida e enfatiza a importância de sua conservação.

Palavras-chave: Mata Atlântica; Conservação; Endemismo; Herpetofauna; Inventário. 


\section{Introduction}

The Brazilian Atlantic Forest biome is one of the world's biodiversity hotspots (Myers et al. 2000), although it has now been reduced to only around $12 \%$ of its original cover as a result of centuries of intense deforestation (Ribeiro et al. 2011, SOS Mata Atlântica, INPE 2018). Approximately 625 amphibian species (Haddad et al. 2013, Rossa-Feres et al. 2017) and 300 reptiles (Tozetti et al. 2017) are known to occur in this biome, and new species are still being steadily described (e.g., Cruz et al. 2019, Maciel et al. 2019, Prates et al. 2019). In the state of Rio de Janeiro, 201 species of amphibian have been recorded, including 197 anurans and four caecilians (Dorigo et al. 2018), together with 149 reptiles (Oliveira et al. 2020). This state has a high rate of endemism of both amphibians (Dorigo et al. 2018, Rossa-Feres et al. 2017) and reptiles (Tozetti et al. 2017), and its metropolitan region is considered to be an important area for the conservation of Brazilian biodiversity (Oliveira et al. 2019).

The state capital, Rio de Janeiro, which has a population of more than six million inhabitants, includes one of the world's largest urban parks, the Parque Nacional da Tijuca (PNT), which is the only Brazilian national park located within an urban zone. Like other coastal ranges within the Atlantic Forest domain, the Tijuca massif has a rich network of water courses (Coelho Netto 2005), which favors the occurrence of amphibians. During the 18th and 19th centuries, however, the forest of this area was almost totally destroyed for the production of charcoal, and the establishment of sugarcane and coffee plantations (Rocha et al. 2003, Rocha 2017). As a result, many of the water sources that supplied the city began to dry up (Abreu \& Rodrigues 2010, Rocha 2017). It seems likely that fragments of forest persisted in many of the more inaccessible areas within the Tijuca massif, in particular, the highest mountain peaks and the steepest valleys (Coimbra-Filho et al. 1973). In addition to providing seeds of native species for the subsequent reforestation of the area (Coimbra-Filho et al. 1973, Abreu \& Rodrigues 2010), these forest remnants probably also provided important refuges for many local animal species (e.g., Rocha et al. 2003). The deforested areas once covered by plantations were almost completely reconstituted by a reforestation project - the first major project of its kind anywhere in the world - which involved the planting of 100,000 trees, beginning in the second half of the 19th century during the Brazilian Empire period. This initiative resulted in the establishment of an exuberant forest, which was converted into a national park in 1961 (Brasil 1961).

In addition to the PNT, two other large parks are found within the urban zone of Rio de Janeiro - the Parque Estadual da Pedra Branca and the Parque Natural Municipal da Serra do Mendanha (PNM Serra do Mendanha). The PNT has a long history of scientific research, first being visited by naturalists during the 19th and 20th centuries. These naturalists described a number of amphibian species based on specimens collected in this area, including Aplastodiscus albofrenatus (Lutz, 1924), Dendrophryniscus brevipollicatus Jiménez de la Espada 1870, Ischnocnema guentheri (Steindachner, 1864), Ischnocnema octavioi (Bokermann, 1965), Phasmahyla guttata (Lutz, 1924), and Scinax trapicheiroi (A. Lutz and B. Lutz, 1954). More recently, herpetofaunal researches in the park included studies of the ecology, natural history or bioacoustics of some taxa (e.g., Heyer 1973, Hepp \& Carvalho-e-Silva 2011, Dorigo et al. 2014, Machado et al. 2016, Hepp et al. 2017, Silvae-Souza 2019, Guarabyra et al. 2020). Introductory lists of amphibian species (Carvalho-e-Silva et al. 2008) and reptiles (Mocelin 2008) were compiled for the management plan of this conservation unit (ICMBIO 2008), although, up to the present time, no systematic inventory has been produced. Given this, we inventoried the herpetofauna of the PNT over a three-year period, using intensive sampling to obtain species composition and estimates of the richness and abundance of the park's amphibians and reptiles. We supplemented our inventory with records of occurrence obtained from herpetological collections and species reintroduction programs in PNT.

\section{Material and Methods}

\section{Study area}

The Parque Nacional da Tijuca $\left(22^{\circ} 55^{\prime}-23^{\circ} 00^{\prime}\right.$ S, $43^{\circ} 11^{\prime}-43^{\circ} 19^{\prime}$ W) is located in the Tijuca massif in the city of Rio de Janeiro, capital of the state of Rio de Janeiro, southeastern Brazil. The park covers a total area of 3,958.38 hectares of dense ombrophilous forest at altitudes between $80 \mathrm{~m}$ and 1,021 $\mathrm{m}$ above sea level (a.s.l.). The park is divided officially into four sectors (ICMBIO 2008): Sector A - the Tijuca Forest, Sector B - the Carioca Mountains, Sector C - Pedra Bonita/ Pedra da Gávea, and Sector D - Pretos-Forros/Covanca (Figure 1). The landscape of the park encompasses a range of land uses and vegetation cover, from forest encompassing distinct stages of succession, to open fields, rocky outcrops, as well as infrastructure, such as buildings and roads (Coelho Netto 2005).

The climate is of the $A w$ type (humid tropical) in the Köppen classification, with intense rains during the austral summer and drier conditions during the winter. Mean monthly temperatures range from $25^{\circ} \mathrm{C}$ in February to $19^{\circ} \mathrm{C}$ in June, with an annual mean of approximately $22^{\circ} \mathrm{C}$. Annual precipitation is typically between 2,000 and $2,500 \mathrm{~mm}$, although it may reach $3,300 \mathrm{~mm}$ in exceptionally rainy years (Coelho Netto 2005, ICMBIO 2008).

\section{Data collection}

We searched for amphibians and reptiles in the Sector A of the park over a 36-month period, between January 2013 and December 2015, at altitudes between $400 \mathrm{~m}$ and $800 \mathrm{~m}$ a.s.l. The searches were based on the Visual Encounter Survey (VES) method of Crump \& Scott (1994), and resulted in a total sampling effort of 460 person-hours, with 230 hours of diurnal and 230 hours of nocturnal searches. When conducting an active search, always two researchers moved through the forest searching systematically for amphibians and reptiles in microhabitats such as streams, ponds, bromeliads, the leaf litter, tree trunks, and rocks. The searches were conducted only in a single direction, to avoid the resampling of individuals, thus guaranteeing the independence of the records. All individuals encountered during searches were captured, identified, and most of them released at the capture site. We collected voucher specimens, which we deposited in the herpetological collection of the Museu Nacional (MNRJ), Universidade Federal do Rio de Janeiro (voucher number in Appendix 1). We complemented our inventory with secondary records, which included data from herpetological collections (Appendix 2), and from a faunal reintroduction project for the PNT. We applied the scientific nomenclature proposed by Frost (2020) for the amphibian species. For the reptiles, we used the nomenclature of Costa and Bérnils (2018), which we updated whenever necessary, based on Poe et al. (2017) and Hoogmoed et al. (2019). 


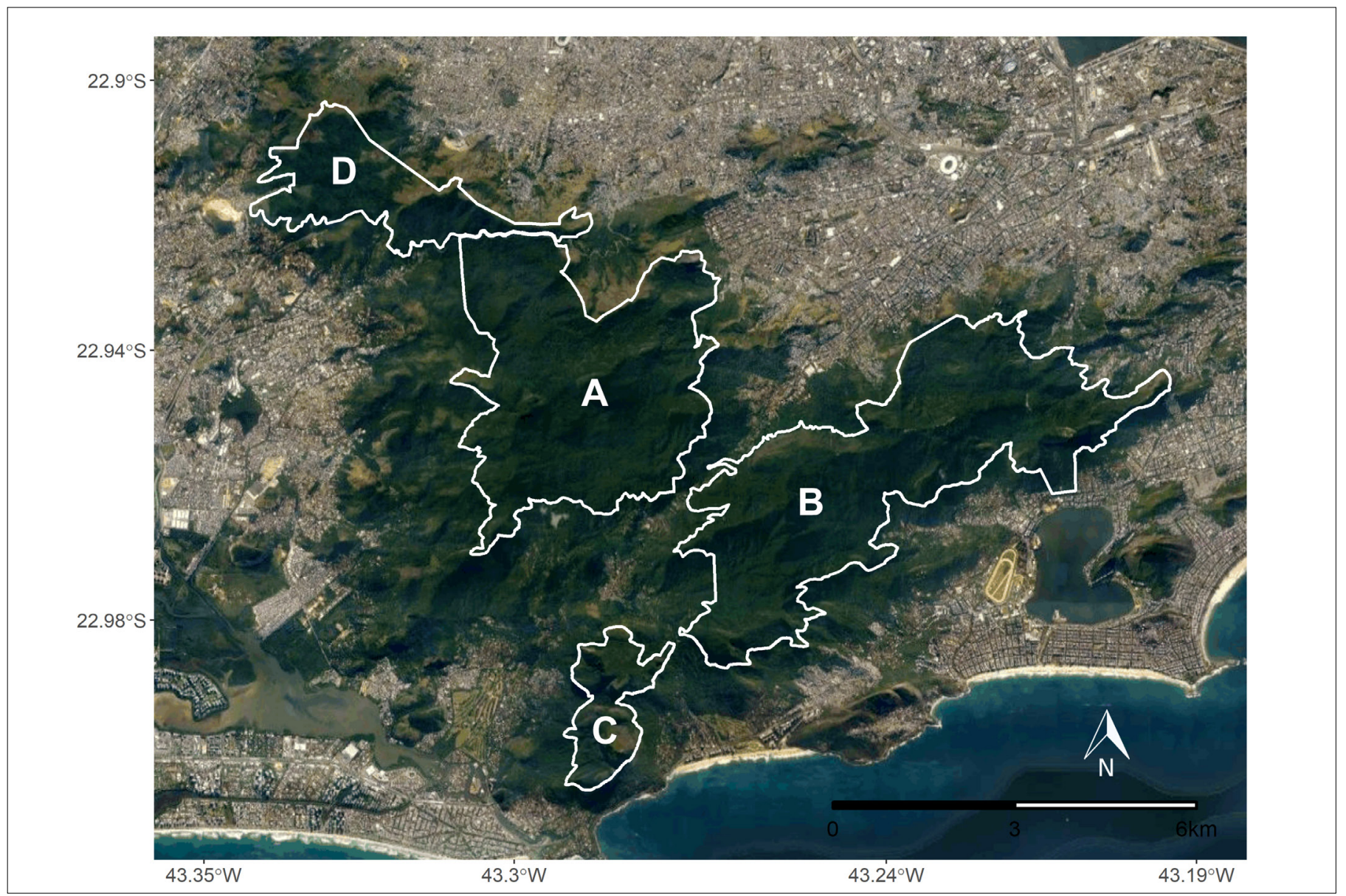

Figure 1. Location of Parque Nacional da Tijuca in the municipality of Rio de Janeiro, state of Rio de Janeiro, southeastern Brazil. The area of the park is divided officially into four sectors: A) Tijuca Forest; B) Carioca Mountains; C) Pedra Bonita/Pedra da Gávea; D) Pretos-Forros/Covanca. Map created with QGIS software (www.qgis.org), using a shapefile from ICMBIO (www.icmbio.gov.br)

\section{Data analysis}

We calculated rarefaction curves and confidence intervals (95\%) with the moment-based estimator of species richness (Colwell et al. 2004) to verify the efficiency of the sampling effort in terms of the number of species recorded during the study for both amphibians and reptiles. For this analysis, one hour of VES constituted a sampling unit, with a total of 460 samples being obtained during the study period as a whole. We considered the convergence of the confidence intervals to zero as an indicator of sampling sufficiency (Colwell et al. 2004). We also estimated the number of species and standard deviation with the Bootstrap richness estimator (Smith \& van Belle 1984) with 1,000 runs. Both the rarefaction curves and Bootstrap were calculated in the program EstimateS 8.2.0 (Colwell 2009). We analyzed the distribution of the species abundance, using rank abundance curves or Whittaker plots (Whittaker 1965), which show the ranked log abundance of each species (Krebs 1999). We analyzed these plots in PAST 2.17 (Hammer et al. 2001).

Species endemism in the Atlantic Forest was defined for the amphibians based on Lingnau et al. (2008), Haddad et al. (2016), and Frost (2020), and for reptiles according to Tozetti et al. (2017). We defined the conservation status of each species based on the IUCN Red List (IUCN 2020), the Red List of Threatened Brazilian Fauna (ICMBIO 2018), and the List of the Threatened Fauna of Rio de Janeiro state (Bergallo et al. 2000). The population trend for each species was obtained from IUCN (2020).

\section{Results}

We recorded a total of 74 species of herpetofauna (distributed in four orders), being 38 amphibians (37 anurans and one caecilian; Table 1) and 36 reptiles (three chelonians, one amphisbaenian, nine lizards, and 23 snakes; Table 2) at the PNT. Hylidae was the amphibian family with the highest species richness ( $\mathrm{N}=10$ species), followed by Brachycephalidae $(\mathrm{N}=5)$ and Cycloramphidae $(\mathrm{N}=5$ ) (Table 1). With the exception of Gymnophthalmidae, with two species, all lizard families were represented by only a single species. The snake family Dipsadidae was represented by 14 species, and Colubridae by five (Table 2). During our field surveys we recorded a total of 3,288 individuals in Sector A of the Parque Nacional da Tijuca, during the 36 months of the study period, representing a total of 49 species. Most $(3,174)$ of these individuals were amphibians (Table 1), belonging to 24 species of the orders Anura ( $\mathrm{N}=23$ species) and Gymnophiona $(\mathrm{N}=1)$ (Figures 2-4). We recorded only 114 reptiles, although these individuals also represented 25 species (Table 2), distributed in two orders, Chelonia $(\mathrm{N}=2)$ and Squamata $(\mathrm{N}=23)$ (Figures 5-7). Two of these amphibian species and 11 of the reptiles were recorded opportunistically during the study period (i.e., not during standardized surveys; Tables 1 and 2).

The cumulative curve for the amphibian species reached the asymptote at 213 hours of sampling with a total richness of 22 species, while the curve for the reptiles reached the asymptote at 276 hours, 
Dorigo, T.A. et al.

Table 1. Amphibian species recorded in Parque Nacional da Tijuca in the municipality of Rio de Janeiro, state of Rio de Janeiro, southeastern Brazil, with data on total abundance (Ab; number of records) and relative abundance (RA; percentage of all recorded amphibians) for the species recorded during the Visual Encounter Surveys are given. Other information include: the conservation status of each species based on their category of threat in the international (IUCN 2020), Brazilian (ICMBIO/MMA 2018), and Rio de Janeiro (RJ) state lists (Bergallo et al. 2000); whether they are endemic (End) to the Atlantic Forest (AF) or to Rio de Janeiro state (RJ) or exotic (Ex); their population trend (PT; IUCN 2020); and Sectors of PNT (ICMBIO 2008) where each species was recorded based on primary (P; see Appendix 1) or secondary (S; see Appendix 2) data. * Species recorded in non-standardized encounters. Conservation status: DD = Data Deficient, LC $=$ Least Concern, VU $=$ Vulnerable, EN $=$ Endangered, and PA = Presumably Threatened ("Presumivelmente Ameaçada"). Population trend: $\mathrm{D}=$ Decreasing; $\mathrm{St}=\mathrm{Stable}$; $\mathrm{U}=\mathrm{Unknown}$

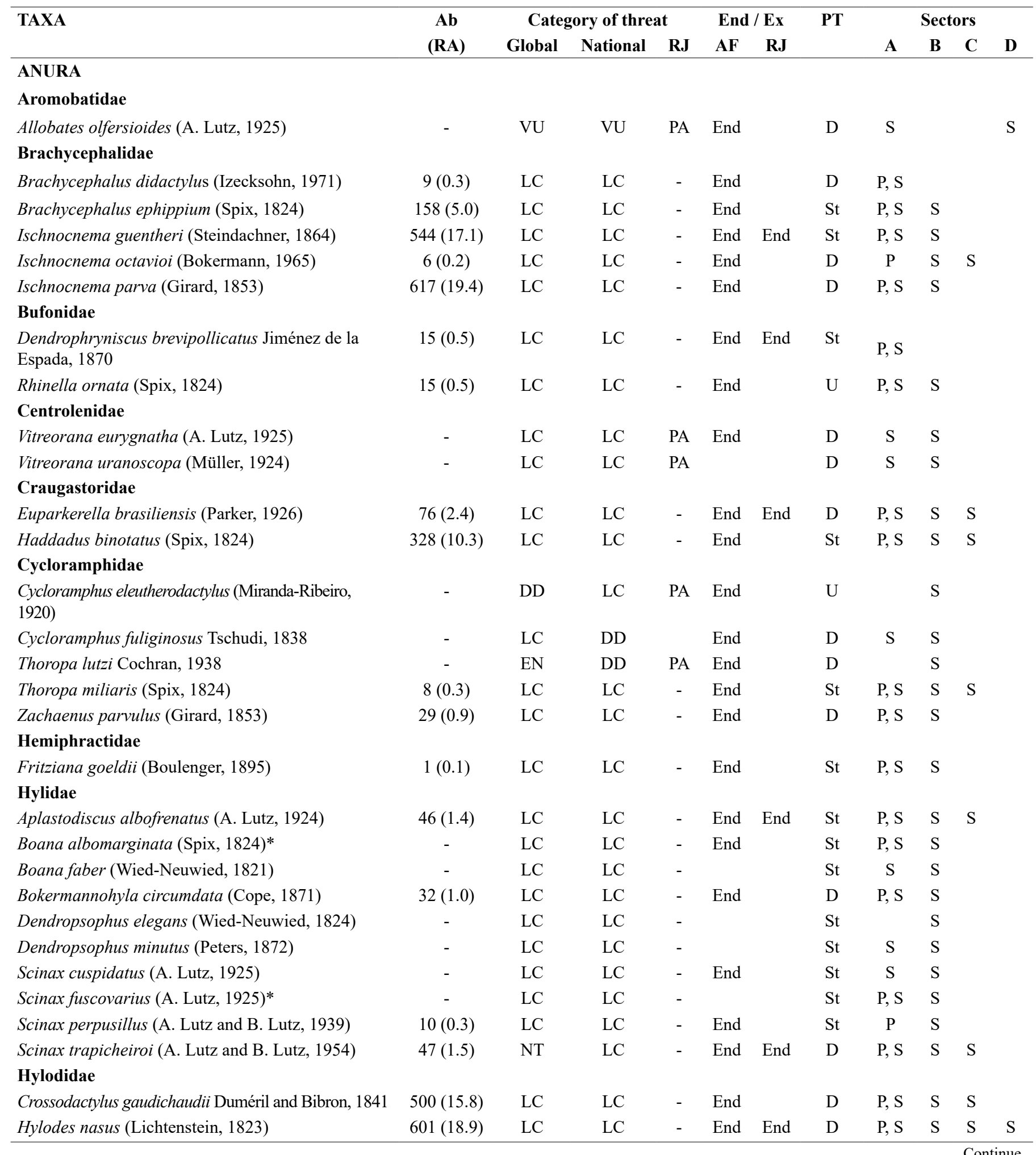


...Continuation

\begin{tabular}{|c|c|c|c|c|c|c|c|c|c|}
\hline \multicolumn{10}{|l|}{ Leptodactylidae } \\
\hline Adenomera marmorata Steindachner, 1867 & $13(0.4)$ & $\mathrm{LC}$ & $\mathrm{LC}$ & - & & St & $\mathrm{P}, \mathrm{S}$ & $\mathrm{S}$ & $\mathrm{S}$ \\
\hline Leptodactylus latrans (Steffen, 1815) & - & $\mathrm{LC}$ & $\mathrm{LC}$ & - & & St & & $\mathrm{S}$ & \\
\hline Physalaemus signifer (Girard, 1853) & $6(0.2)$ & LC & $\mathrm{LC}$ & - & End & St & $\mathrm{P}, \mathrm{S}$ & $\mathrm{S}$ & \\
\hline \multicolumn{10}{|l|}{ Microhylidae } \\
\hline Myersiella microps (Duméril and Bibron, 1841) & - & LC & $\mathrm{LC}$ & - & End & $\mathrm{St}$ & $\mathrm{S}$ & $\mathrm{S}$ & \\
\hline \multicolumn{10}{|l|}{ Odontophrynidae } \\
\hline Proceratophrys boiei (Wied-Neuwied, 1824) & - & LC & $\mathrm{LC}$ & - & End & St & $\mathrm{S}$ & $\mathrm{S}$ & \\
\hline \multicolumn{10}{|l|}{ Phyllomedusidae } \\
\hline Phasmahyla guttata (Lutz, 1924) & $108(3.4)$ & $\mathrm{LC}$ & $\mathrm{LC}$ & - & End & $\mathrm{D}$ & $\mathrm{P}, \mathrm{S}$ & $\mathrm{S}$ & \\
\hline Phyllomedusa burmeisteri Boulenger, 1882 & - & $\mathrm{LC}$ & $\mathrm{LC}$ & - & & $\mathrm{St}$ & $\mathrm{S}$ & $\mathrm{S}$ & $\mathrm{S}$ \\
\hline \multicolumn{10}{|l|}{ GYMNOPHIONA } \\
\hline \multicolumn{10}{|l|}{ Siphonopidae } \\
\hline Siphonops hardyi Boulenger, 1888 & $5(0.2)$ & $\mathrm{LC}$ & $\mathrm{LC}$ & - & End & St & $\mathrm{P}$ & & \\
\hline
\end{tabular}

with a total of 14 species, based on a total sampling effort of 460 hours (Figure 8). The confidence intervals of the rarefaction curves converged to zero for the amphibians, but not for the reptiles, for which the error was estimated as 2.3 species (Figure 8 ). The species richness estimated by the Bootstrap procedure was similar to that recorded by the VES method for both amphibians (estimated richness $=22.4$ species) and reptiles (estimated richness $=15.6$ species).

The Whittaker plots (Figure 9) revealed considerable variation in the abundance of the amphibian and reptilian species, which was best adjusted using the log-series model. The most abundant amphibian species (Table 1) were Ischnocnema parva ( $\mathrm{N}=617$ records; $19.4 \%$ of all amphibians), Hylodes nasus $(\mathrm{N}=601 ; 18.9 \%)$, Ischnocnema guentheri $(\mathrm{N}=544 ; 17.1 \%)$, and Crossodactylus gaudichaudii $(\mathrm{N}=500 ; 15.8 \%)$. The most abundant reptiles were the lizards Enyalius brasiliensis ( $\mathrm{N}=55 ; 48.2 \%$ of all reptiles) and Ecpleopus gaudichaudii $(\mathrm{N}=15 ; 13.2 \%)$, representing $61.4 \%$ of all the reptiles recorded during the surveys (Table 2). The most abundant snakes were Bothrops jararacussu ( $\mathrm{N}=8 ; 7.0 \%$ of all reptiles), Thamnodynastes cf. nattereri $(\mathrm{N}=7 ; 6.1 \%)$, and Bothrops jararaca $(\mathrm{N}=6 ; 5.3 \%)$.

Overall, 30 of the amphibian (ca. $80 \%$ of the total) and ten of the reptile species (28\%) recorded in the PNT are endemic to the Atlantic Forest biome (Tables 1 and 2). Six of these amphibians - Aplastodiscus albofrenatus, Dendrophryniscus brevipollicatus, Euparkerella brasiliensis, Hylodes nasus, Ischnocnema guentheri, and Scinax trapicheiroi - are considered endemic to the state of Rio de Janeiro. Most of the amphibian and reptile species are listed as Least Concern or Not Threatened in the three lists of conservation status (international, Brazilian, and state). Six amphibian and one reptile species recorded in the PNT are listed under some category of extinction threat. The populations of 15 amphibian species are thought to be declining (Table 1). Two of the reptile species, the lizard Hemidactylus mabouia and the chelonian Trachemys scripta are exotic (Table 2).

\section{Discussion}

\section{Biodiversity: species richness, composition, and abundance}

The results of the present study indicate that the forests of the PNT harbor for a large proportion of the herpetofaunal diversity of the Atlantic Forest of the state of Rio de Janeiro. Considering both the records obtained during our fieldwork and from secondary data, the park's amphibian species richness would amount to at least 38 species, which represent $19 \%$ of the amphibians known to occur in the state $(\mathrm{N}=201$ species; Dorigo et al. 2018), 6\% of the amphibian species from Atlantic Rainforest ( $\mathrm{N}=600$; Rossa-Feres et al. 2017), and 3\% of the amphibian fauna of Brazil $(N=1,136$; Segalla et al. 2019). The combination of primary and secondary data also indicates the occurrence of 36 reptile species in the PNT, which represent $24 \%$ of the reptiles known to occur in the whole Rio de Janeiro state $(\mathrm{N}=149$; Oliveira et al. 2020), $12 \%$ of the species recorded in the Atlantic Rainforest $(\mathrm{N}=$ 300; Tozetti et al. 2017), and $4 \%$ of the country's reptilian diversity ( $\mathrm{N}=$ 795 species; Costa \& Bérnils 2018). When considering the sampled area and the effort employed, the number of amphibian and reptile species recorded during surveys in PNT is consistent with the expected. In fact, the cumulative species curves for both groups reached the asymptote by around the middle of the study period, indicating that sampling effort was adequate in both cases. Similarly, while the confidence intervals of the rarefaction curves for the amphibians converged to zero, indicating sampling sufficiency, those calculated for the reptiles approached the convergence, with reduced estimated error.

In comparison with the PNM Serra do Mendanha - other substantial remnant of dense rainforest in the urban zone of Rio de Janeiro for which systematic medium-term data are available - the results of the present study are broadly consistent. Pontes et al. (2015) recorded 45 amphibians and 39 reptiles at PNM Serra do Mendanha, values closely comparable with the 38 amphibians and 36 reptiles we recorded at PNT. The amphibian species richness recorded in the PNT is also relatively high in comparison with other forested areas in the state of Rio de Janeiro for which data are available (Table 3). While the species richness recorded at the different sites fluctuates considerably, it seems likely that much of this variation is related to differences in survey methods, sampling effort, and the study period (Table 3 ).

The reptilian species richness recorded in the PNT was also relatively high in comparison with the data from other Atlantic Forest remnants in the state of Rio de Janeiro, as recorded in both short-term (Morro São João, Casimiro de Abreu, $\mathrm{N}=9$ species; Almeida-Gomes et al. 2008) and medium-term studies (Reserva Ecológica de Guapiaçu, 
Dorigo, T.A. et al.

Table 2. Reptile species recorded in Parque Nacional da Tijuca in the municipality of Rio de Janeiro, state of Rio de Janeiro, southeastern Brazil, with data on total abundance (Ab; number of records) and relative abundance (RA; percentage of all recorded amphibians) for the species recorded during the Visual Encounter Surveys are given. Other information include: the conservation status of each species based on their category of threat in the international (IUCN 2020), Brazilian (ICMBIO/MMA 2018), and Rio de Janeiro (RJ) state lists (Bergallo et al. 2000); whether they are endemic (End) to the Atlantic Forest (AF) or to Rio de Janeiro state (RJ), or exotic (Ex); their population trend (PT; IUCN 2020); and Sectors of PNT (ICMBIO 2008) where each species was recorded based on primary (P; see Appendix 1) or secondary (S; see Appendix 2) data. * Species recorded in non-standardized encounters. **Visual record only (no specimens collected). *** Refauna Project (Refauna 2019). Conservation status: $\mathrm{NE}=$ Not Evaluated, DD $=$ Data Deficient, LC $=$ Least Concern, VU = Vulnerable, EN = Endangered, and PA $=$ Presumably Threatened ("Presumivelmente Ameaçada"). Population trend: D = Decreasing, I = Increasing, St = Stable, U = Unknown or Unspecified

\begin{tabular}{|c|c|c|c|c|c|c|c|c|c|c|c|}
\hline \multirow[t]{2}{*}{ TAXA } & \multirow{2}{*}{$\begin{array}{c}\text { Ab } \\
\text { (RA) }\end{array}$} & \multirow{2}{*}{$\begin{array}{c}\text { Category } \\
\text { of threat } \\
\text { Global }\end{array}$} & \multirow[b]{2}{*}{ National } & \multicolumn{3}{|c|}{$\begin{array}{l}\text { End } \\
/ \text { Ex }\end{array}$} & \multirow[t]{2}{*}{ PT } & \multicolumn{4}{|c|}{ Sectors } \\
\hline & & & & RJ & $\mathbf{A F}$ & RJ & & $\mathbf{A}$ & B & $\mathrm{C}$ & D \\
\hline
\end{tabular}

\section{CHELONIA}

Emydidae

Trachemys scripta (Thunberg in Schoepff, 1792)*

Testudinidae

Chelonoidis carbonarius (Spix, 1824)*

Chelonoidis denticulatus (Linnaeus, 1766)

SQUAMATA

AMPHISBAENIA

Amphisbaenidae

Leposternon microcephalum Wagler, 1824*

LACERTILIA

Dactyloidae

Anolis punctatus Daudin, 1802*

Gekkonidae

Hemidactylus mabouia (Moreau de Jonnès, 1818)*

Gymnophthalmidae

Ecpleopus gaudichaudii Duméril and Bibron, 1839

Placosoma glabellum (Peters, 1870)*

Leiosauridae

Enyalius brasiliensis (Lesson, 1830)

\section{Mabuyidae}

Psychosaura macrorhyncha (Hoge, 1946)*

Phyllodactylidae

Gymnodactylus darwinii (Gray, 1845)

\section{Teiidae}

Salvator merianae Duméril and Bibron, 1839

Tropiduridae

Tropidurus torquatus (Wied, 1820)*

\section{SERPENTES}

Boidae

Boa constrictor Linnaeus, 1758*

\section{Colubridae}

Chironius bicarinatus (Wied-Neuwied, 1820)

Chironius foveatus Bailey, 1955

Chironius fuscus (Linnaeus, 1758)

Spilotes pullatus (Linnaeus, 1758)

Spilotes sulphureus (Wagler, 1824)

Dipsadidae

$\begin{array}{cccccccc}- & \text { LC } & - & - & \text { Ex } & \text { Ex } & \text { St } & \mathrm{P}^{* *} \\ - & - & \text { LC } & - & & & - & \mathrm{P}^{* *} \\ - & \mathrm{VU} & \text { LC } & - & & & \text { Unsp } & \mathrm{S}^{* * *}\end{array}$

$\begin{array}{llllll}- & - & \text { LC } & - & \text { Unk } & \text { P }\end{array}$

15
$(13.2)$

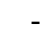

55

$(48.2)$

LC

$\mathrm{LC}$

LC

LC

LC

LC

LC

LC

LC

LC

LC

$4(3.5)$

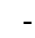


...Continuation

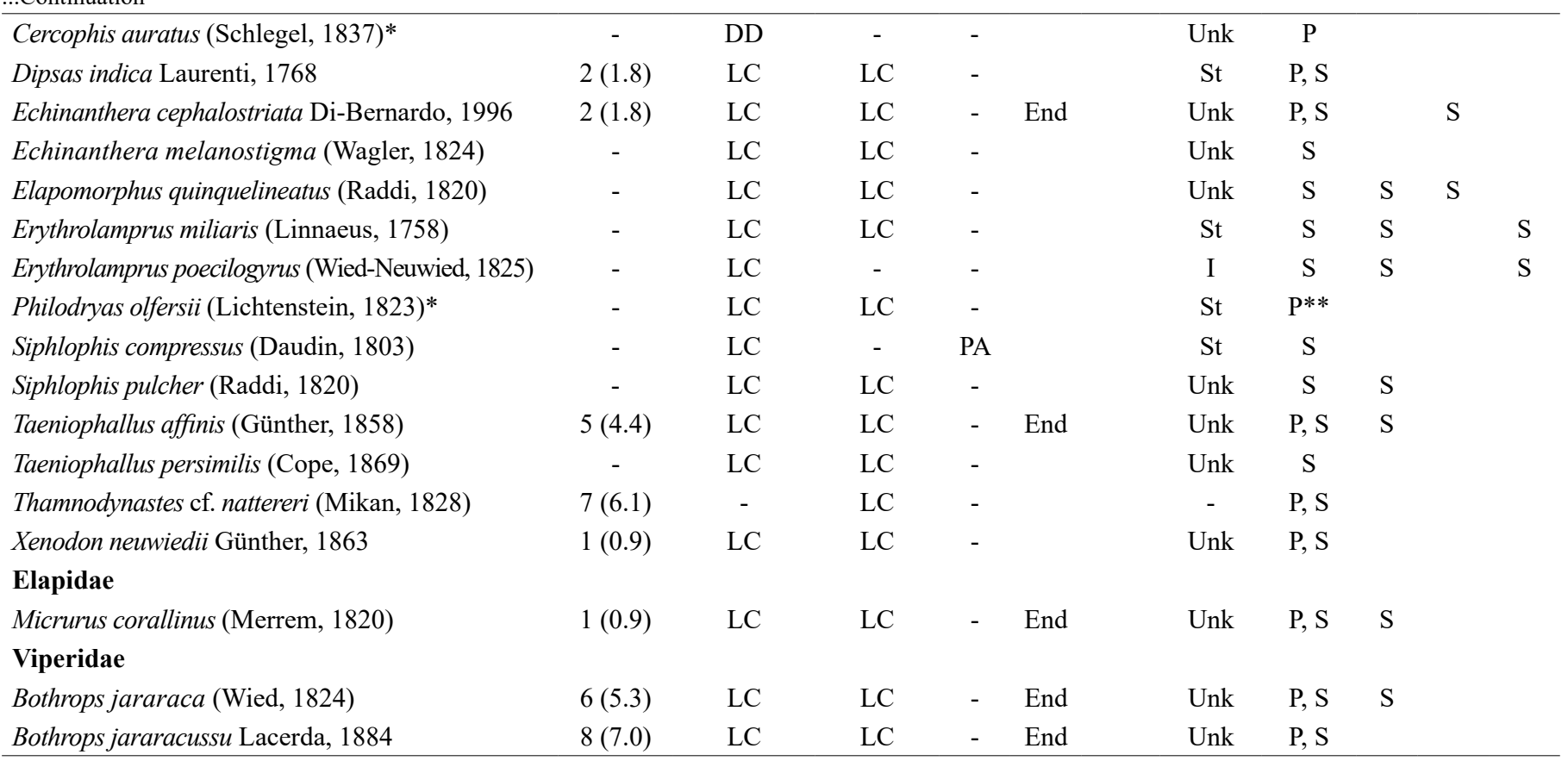
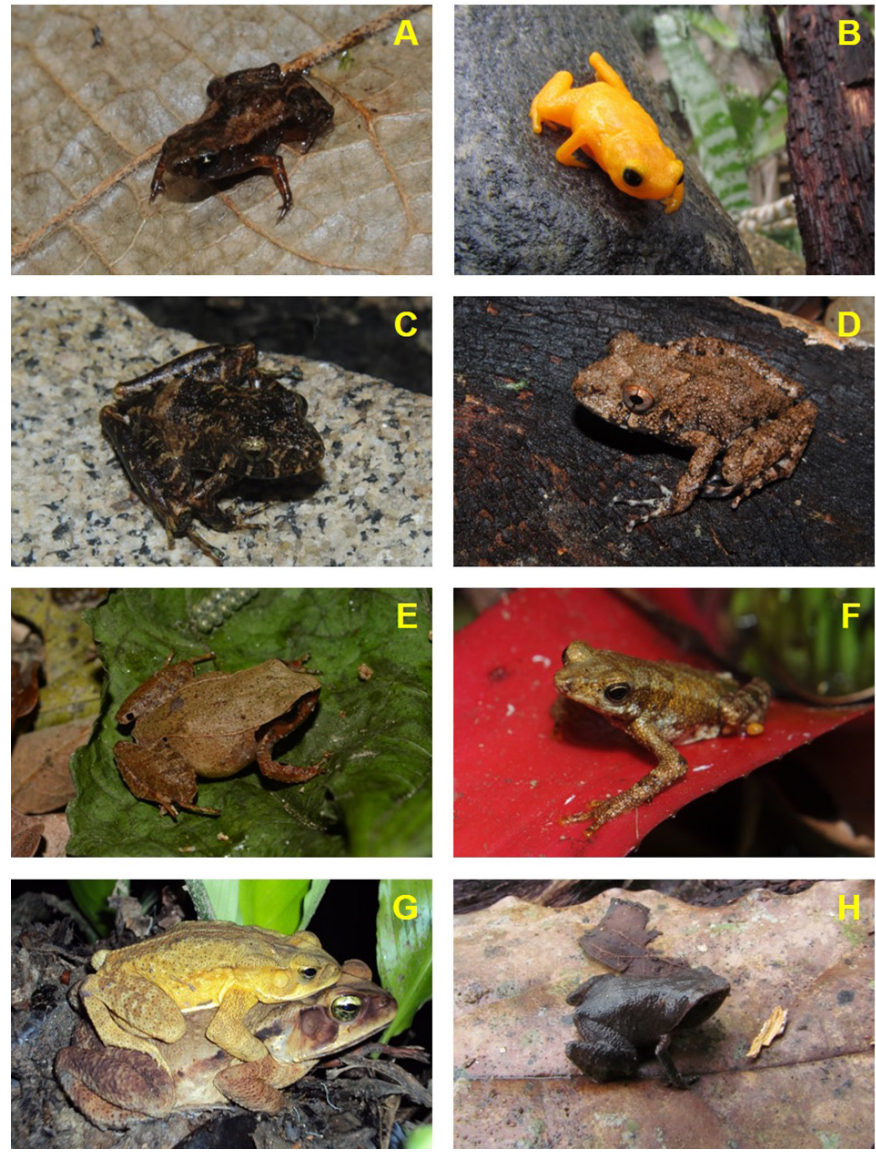

Figure 2. Examples of the anurans recorded during the present study in the Parque Nacional da Tijuca, southeastern Brazil: A) Brachycephalus didactylus; B) Brachycephalus ephippium; C) Ischnocnema guentheri; D) Ischnocnema octavioi; E) Ischnocnema parva; F) Dendrophryniscus brevipollicatus; G) Rhinella ornata; H) Euparkerella brasiliensis. Photographs by T. A. Dorigo
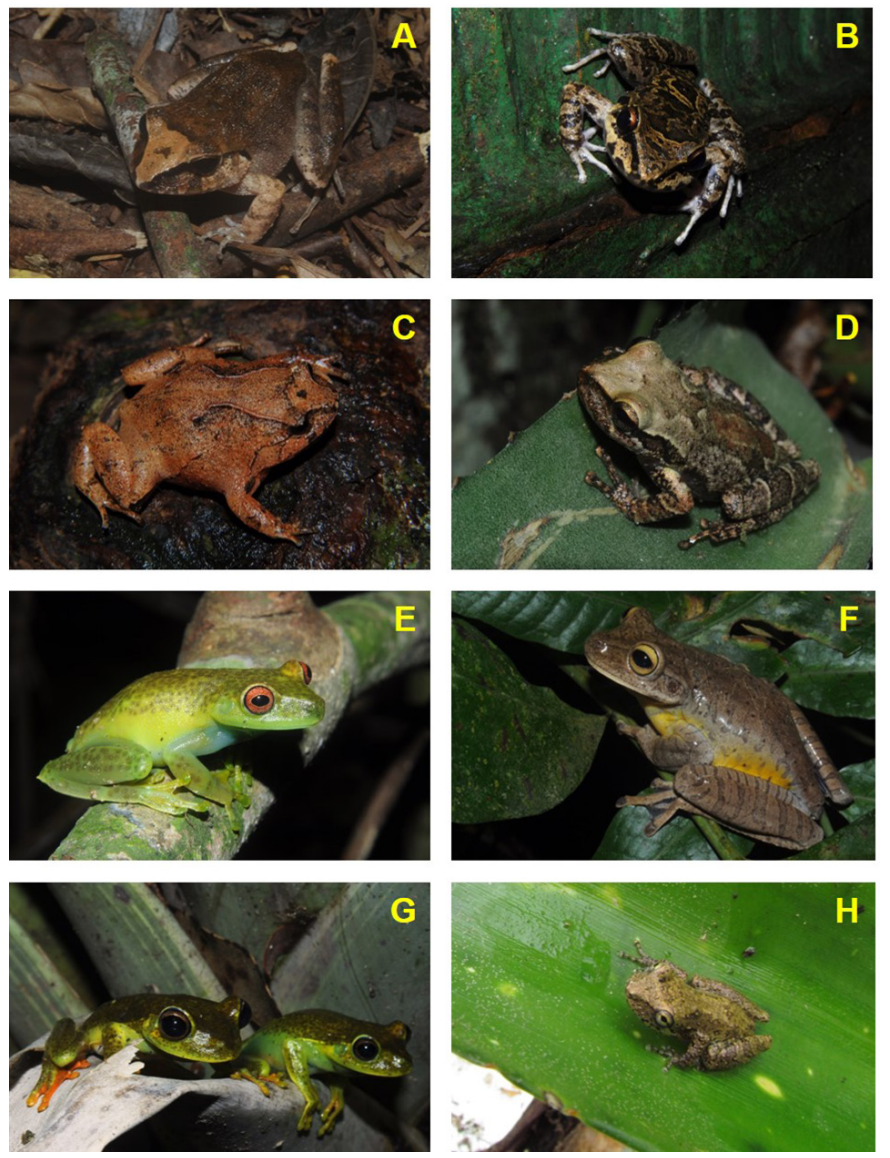

Figure 3. Examples of the anurans recorded during the present study in the Parque Nacional da Tijuca, southeastern Brazil: A) Haddadus binotatus; B) Thoropa miliaris; C) Zachaenus parvulus; D) Fritziana goeldii; E) Aplastodiscus albofrenatus; F) Bokermannohyla circumdata; G) Boana albomarginata; H) Scinax perpusillus. Photographs by T. A. Dorigo 
Dorigo, T.A. et al.
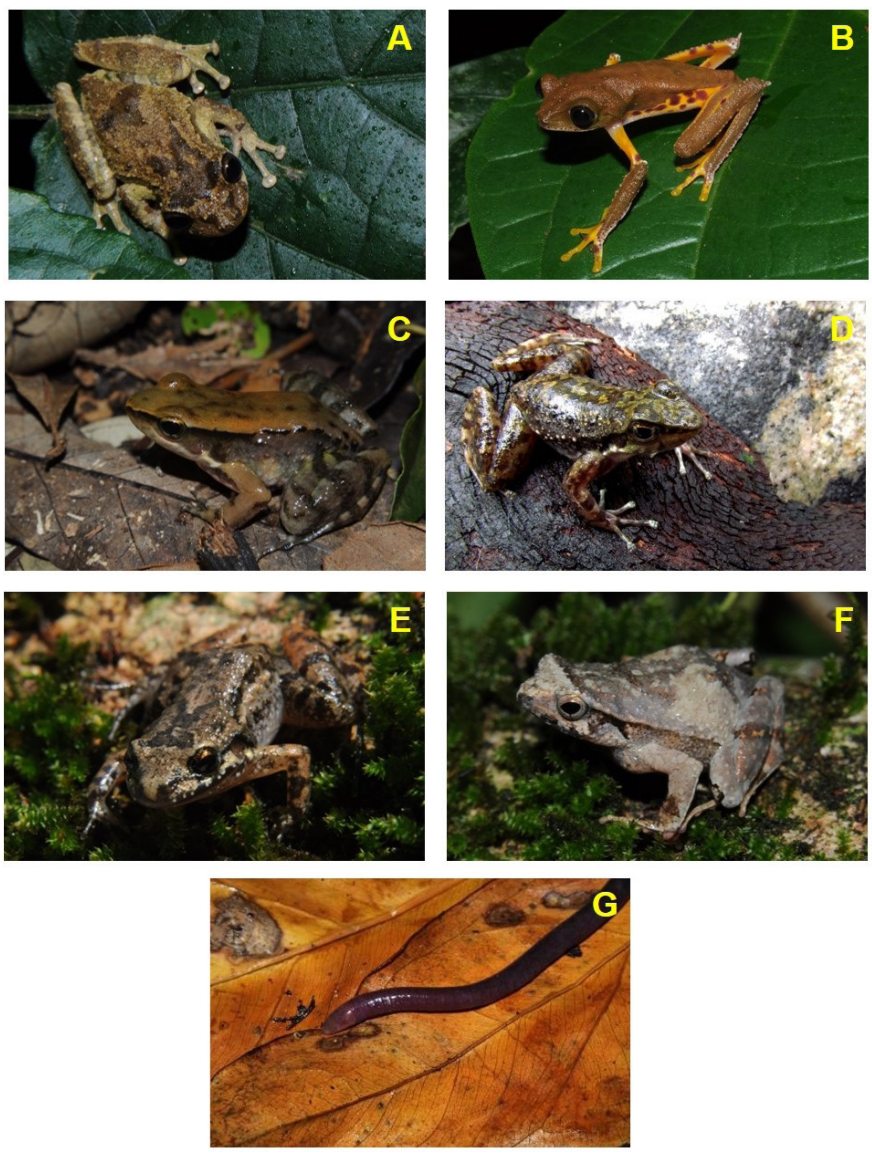

Figure 4. Examples of the amphibians recorded during the present study in the Parque Nacional da Tijuca, southeastern Brazil: A) Scinax trapicheiroi; B) Phasmahyla guttata; C) Crossodactylus gaudichaudii; D) Hylodes nasus; E) Adenomera marmorata; F) Physalaemus signifer; G) Siphonops hardyi (Gymnophiona). Photographs by T. A. Dorigo

$\mathrm{N}=37$ species; Almeida-Gomes et al. 2014a), and even the short-term study of Vrcibradic et al. (2011) at the Estação Ecológica Estadual do Paraíso, which reached a total of 29 species with the inclusion of secondary data.

Hylidae $(\mathrm{N}=10)$ was the most diverse amphibian family in the PNT, followed by Brachycephalidae and Cycloramphidae, with five species. A similar predominance of hylids in the amphibian assemblage has been recorded not only at other Atlantic Forest sites (e.g., Heyer et al. 1990, Almeida-Gomes et al. 2014a, Silva et al. 2017), but also at other localities in the Neotropical region (e.g., Toft \& Duellman 1979, Duellman 1988, Menin et al. 2017). The high diversity of hylids in South America has been explained by the fact that this region is considered to be the center of origin and diversification of this clade (Wiens et al. 2006).

With 14 species, Dipsadidae was the most diverse reptilian family in the PNT, which is consistent with the pattern typically found for the Squamata in Atlantic Forest remnants in the state of Rio de Janeiro (e.g., Pontes et al. 2009, Rocha et al. 2018, Martins et al. 2019). The family Dipsadidae, which is widely distributed in the Americas and West Indies (Hedges et al. 2009, Zaher et al. 2009, Grazziotin et al. 2012), includes the vast majority of the snakes of the Neotropical region, with more than 700 species (see Uetz et al. 2019).
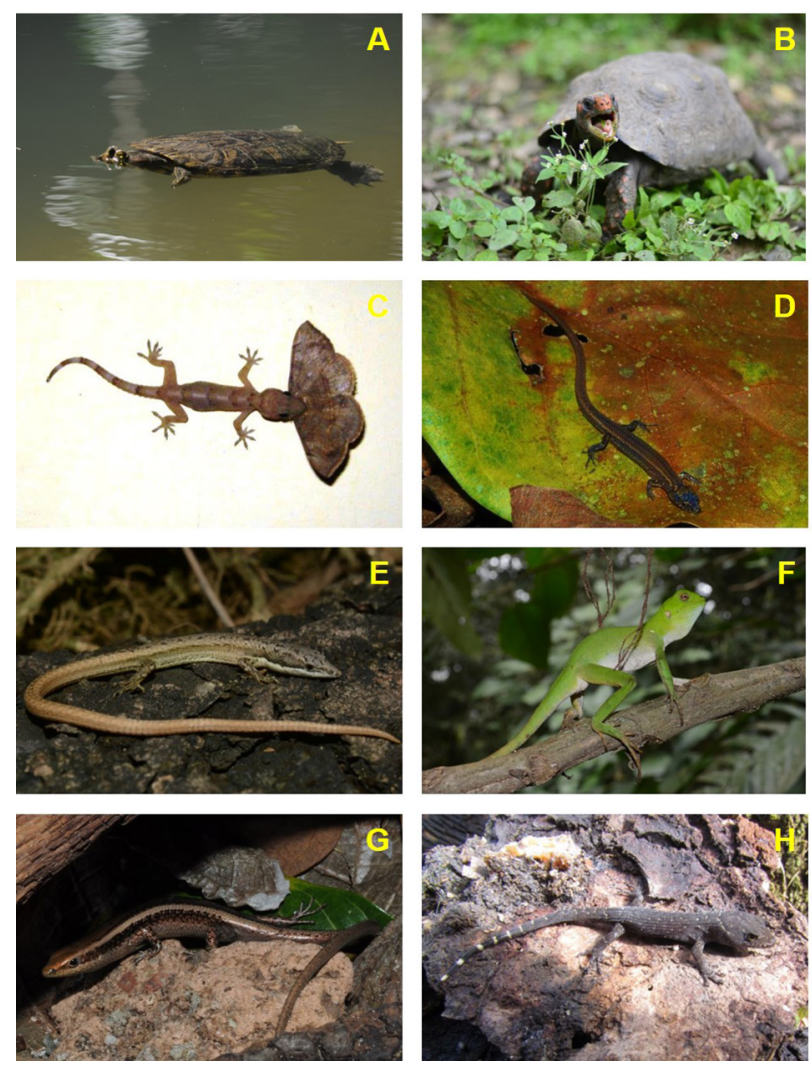

Figure 5. Examples of the reptiles recorded during the present study in the Parque Nacional da Tijuca, southeastern Brazil: A) Trachemys scripta; B) Chelonoidis carbonarius; C) Hemidactylus mabouia; D) Ecpleopus gaudichaudii; E) Placosoma glabellum; F) Enyalius brasiliensis; G) Psychosaura macrorhyncha; H) Gymnodactylus darwinii. Photograph by T. A. Dorigo

The PNT and the PNM Serra do Mendanha (Pontes et al. 2015) shared 25 amphibian species (Sørensen index of similarity $=0.6$; Magurran \& McGill 2011) and 29 reptiles (=0.8). Despite these similarities, 13 amphibian species were exclusive to the PNT, while 27 were exclusive to the Serra do Mendanha. Similarly, seven species of reptiles were exclusive to PNT and ten to the Serra do Mendanha. Similarities of the herpetofauna between these two areas would be accounted at least partly because they would have originally been part of a single continuous forest in the past, and can also be indicative of the effectiveness of the reforestation of the Tijuca massif, carried out during the 19th century (Rocha et al. 2003, Rocha 2017). However, the existence of a unique fauna in both areas also reinforces the importance of the preservation of both forests for the protection of the herpetofauna of the Atlantic Forest in general.

The relative abundance of both amphibian and reptilian species in the PNT was adjusted to a log-series model, a pattern typical of communities of medium diversity, showing certain degree of equilibrium between the rare and dominant species (Magurran \& McGill 2011). In this model, most species are relatively rare in comparison with the more abundant taxa (Magurran 2004). The four most abundant amphibian species (I. parva, H. nasus, I. guentheri, and C. gaudichaudii) contributed to around $70 \%$ of the total records of amphibians obtained in the park. The genus Ischnocnema belongs to the superfamily Brachycephaloidea (sensu Padial et al. 2014), which spawn on the moist forest floor and have direct development, so they do not depend on bodies of water for 

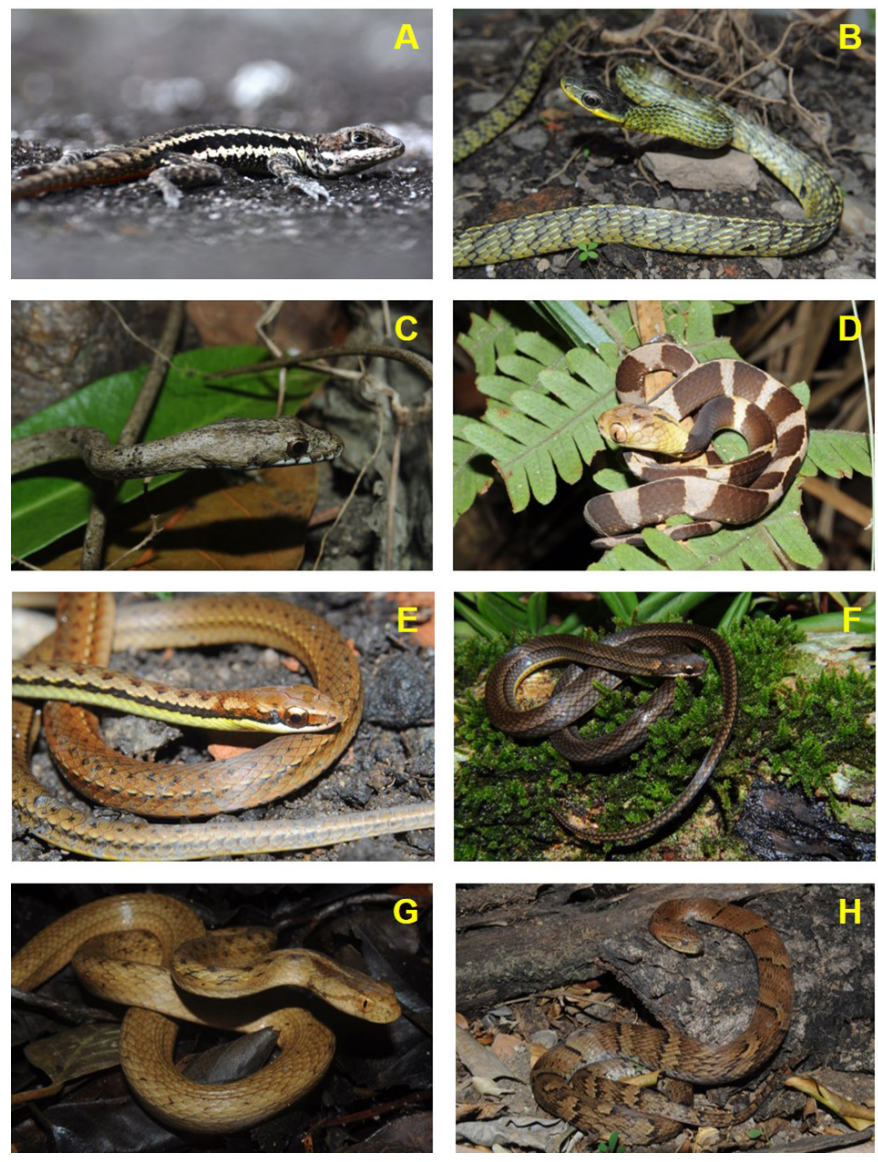

Figure 6. Examples of the reptiles recorded during the present study in the Parque Nacional da Tijuca, southeastern Brazil: A) Tropidurus torquatus; B) Chironius foveatus; C) Cercophis auratus; D) Dipsas indica; E) Echinanthera cephalostriata; F) Taeniophallus affinis; G) Thamnodynastes cf. nattereri; H) Xenodon neuwiedii. Photograph by T. A. Dorigo

their breeding and development (Haddad \& Prado 2005, Pombal \& Haddad 2007). Species that have direct development tend to be dominant in leaf litter-dwelling anuran communities in Neotropical rainforests (e.g., Crump 1971, Allmon 1991, Donnelly 1994, Rocha et al. 2001, Siqueira et al. 2014). Two stream-dwelling frog species, Hylodes nasus and C. gaudichaudii, were the most abundant species recorded at the PNT. Hylodidae species are generally abundant in small streams in preserved Atlantic Rainforest areas (e.g., Weygoldt 1989, Patto \& Pie 2001, Almeida-Gomes et al. 2008, Siqueira et al. 2011b).

The most abundant reptiles in the PNT were Enyalius brasiliensis and Ecpleopus gaudichaudii, and accounted for approximately $60 \%$ of the total reptilian abundance recorded in the present study. Enyalius brasiliensis is typical of forested environments, and was relatively abundant in the area in comparison with other forest remnants in the state of Rio de Janeiro, based on short-term (Morro São João; Almeida-Gomes et al. 2008) or mid-term studies (Guapiaçu Ecological Reserve; Almeida-Gomes \& Rocha 2014a). Ecpleopus gaudichaudii is a Gymnophtalmidae endemic to the Atlantic Forest, which is typically a major component of local leaf-litter reptile communities (e.g., Dixo \& Verdade 2006, Almeida-Gomes \& Rocha 2014a, Cruz et al. 2014).

Two of the three most abundant snakes recorded during our surveys were members of the family Viperidae (B. jararaca and B. jararacussu),
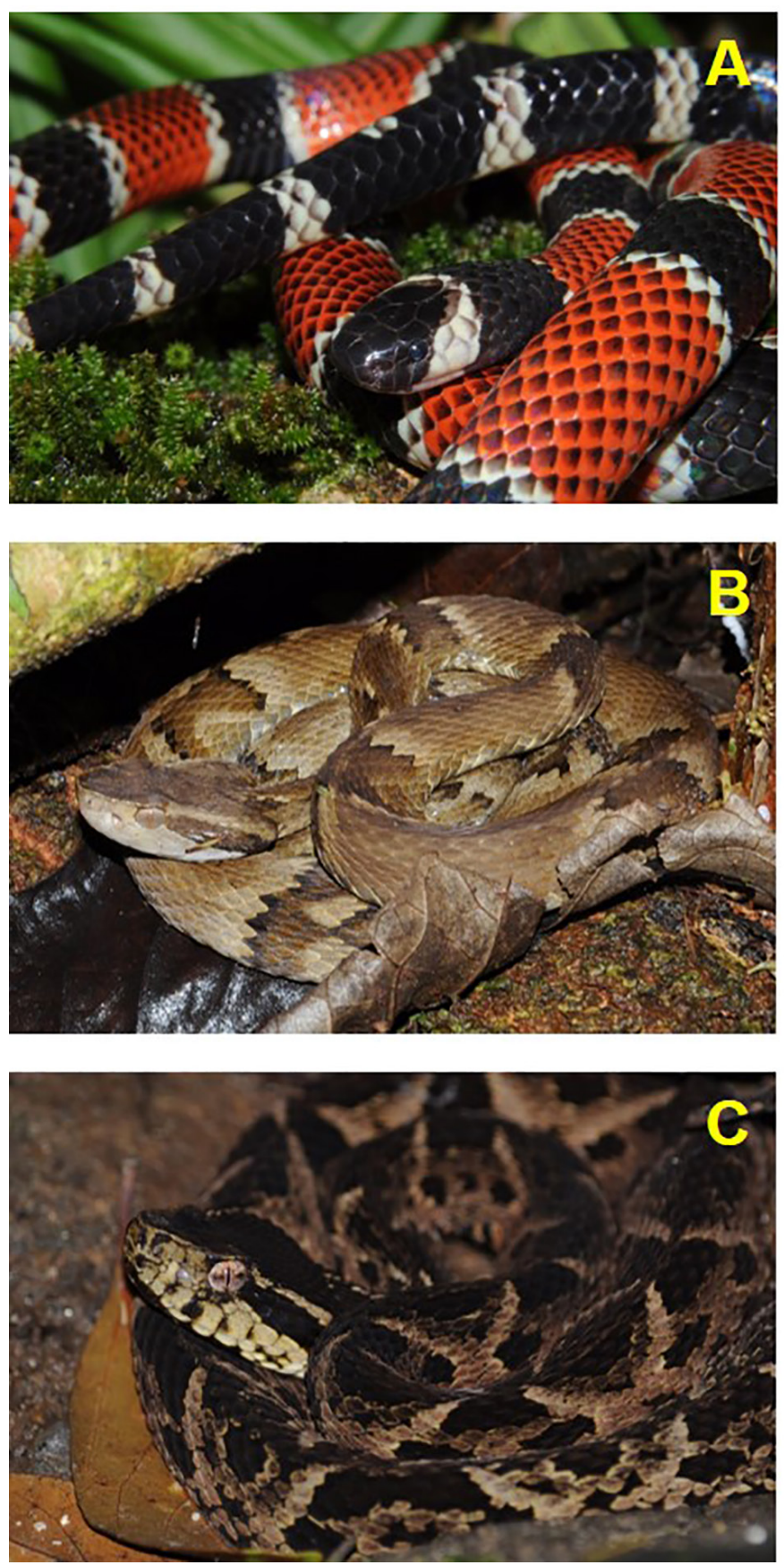

Figure 7. Examples of the reptiles recorded during the present study in the Parque Nacional da Tijuca, southeastern Brazil: A) Micrurus corallinus; B) Bothrops jararaca; C) Bothrops jararacussu. Photograph by T. A. Dorigo

whose representatives are common in areas of mainland Atlantic Forest (Marques \& Sazima 2004, Pontes et al. 2009). The Dipsadidae Thamnodynastes $\mathrm{cf}$. nattereri was the second most abundant snake in the PNT, and was also one of the most abundant in the PNM Serra do Mendanha (Pontes et al. 2009).

\section{Conservation: endemism, threat status, and exotic species}

Most (ca. 80\%) of the amphibian species recorded in the PNT are endemic to the Atlantic Forest (Rossa-Feres et al. 2017). This was somewhat expected, as that biome has a high degree of endemism for amphibians (Haddad et al. 2013). By contrast, only $28 \%$ of the reptilian 

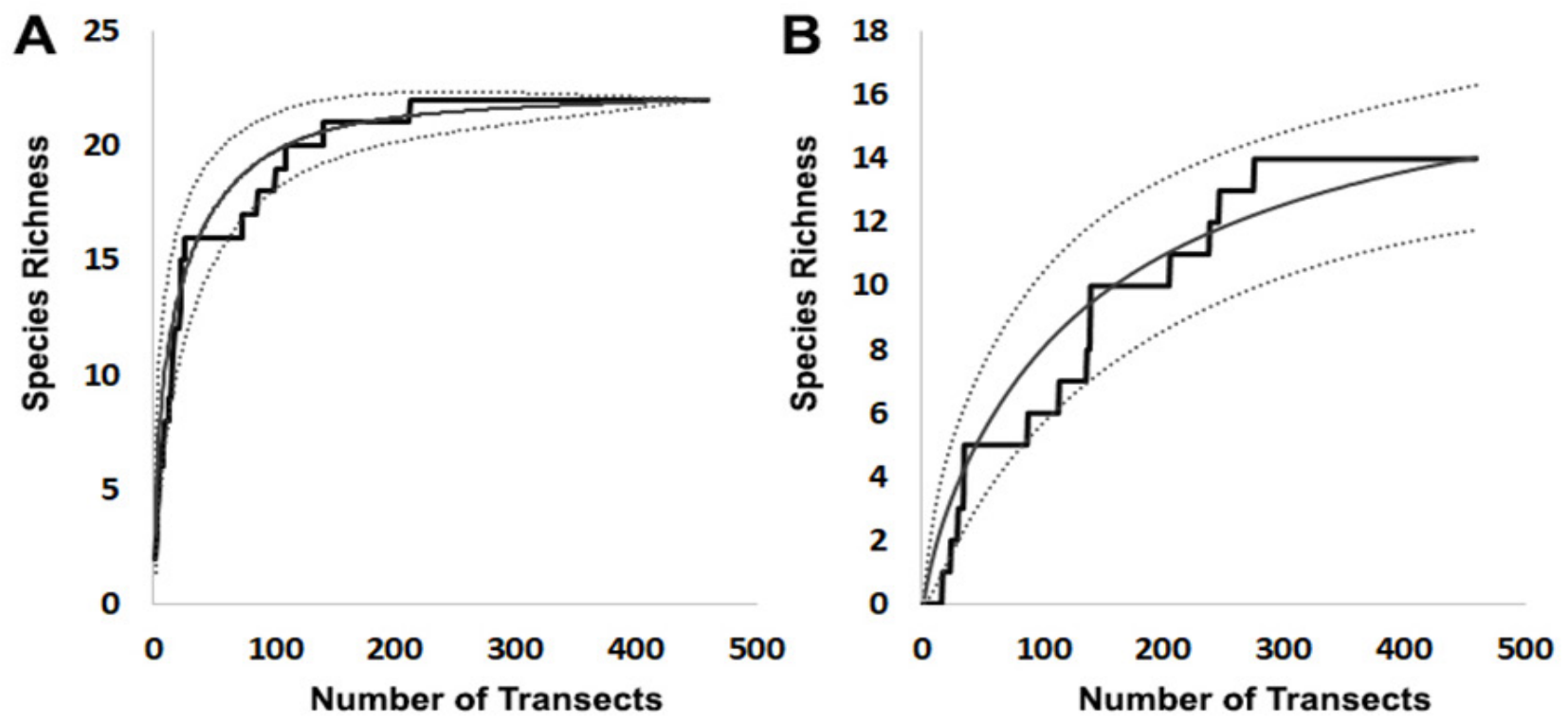

Figure 8. Cumulative (black line) and rarefaction (gray line, with $95 \%$ confidence intervals shown by the dotted lines) curves for the (A) amphibians and (B) reptiles recorded in the Parque Nacional da Tijuca, southeastern Brazil, according to the VES sampling effort (number of hours)
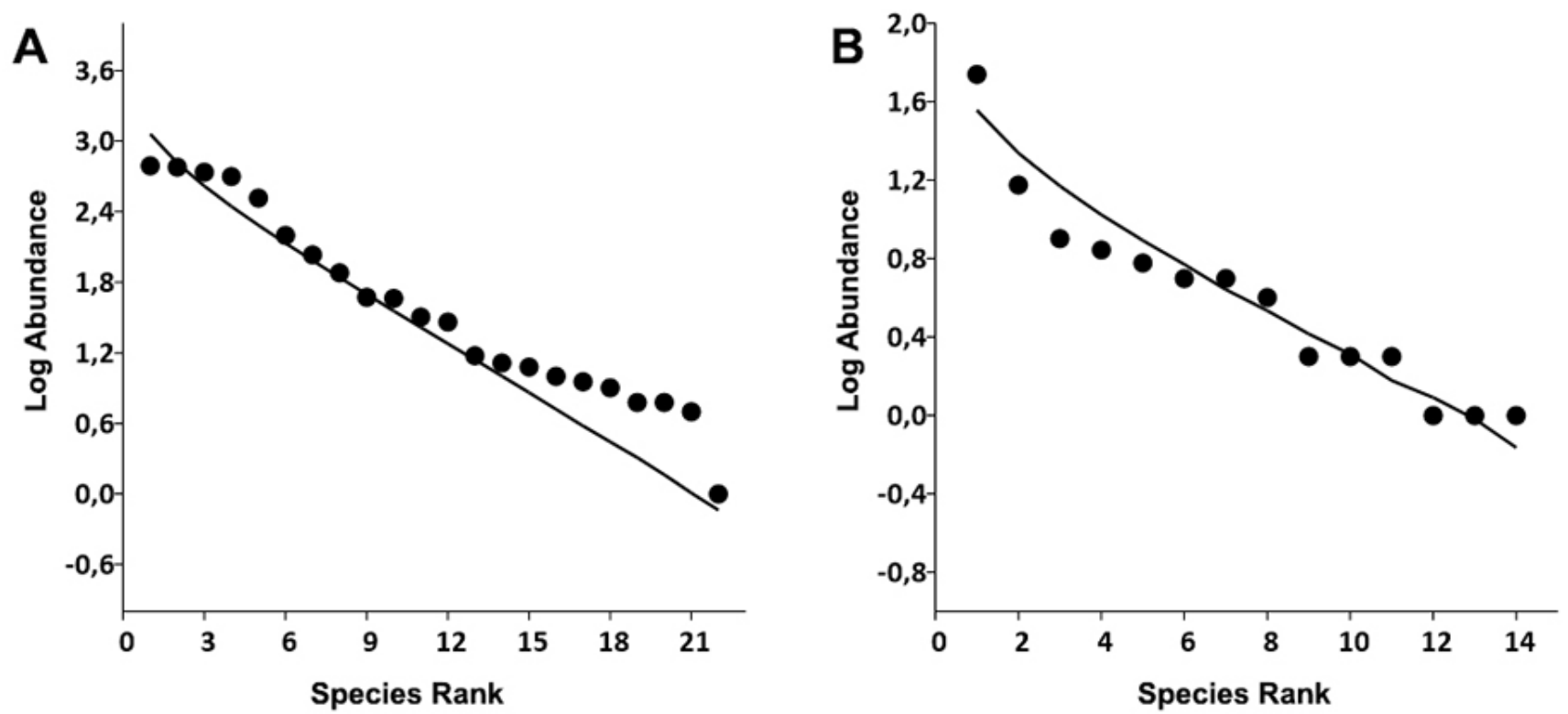

Figure 9. Rank-abundance curves (black dots) with the trend line of the species of (A) amphibians and (B) reptiles recorded by the VES method in the Parque Nacional da Tijuca, southeastern Brazil

species recorded are endemic to the Atlantic Forest, although this is also typical for this group (Tozetti et al. 2017). Six of the amphibians are also considered to be endemic to the state of Rio de Janeiro, including two (H. nasus and I. guentheri) that are endemic to the municipality of Rio de Janeiro. Hylodes nasus is known to be restricted to the forests of this municipality, and has, in fact, only been recorded, up to now, in the PNT (Nascimento et al. 2001, Lingnau et al. 2008) and the PNM Serra do Mendanha (Pontes et al. 2015). However, Canedo (2008) has analyzed specimens that may be associated with H. nasus, which were collected in the municipality of Volta Redonda, in the state of Rio de Janeiro, and also in Cachoeiro de Itapemirim, in the state of Espírito Santo, although further research is required to confirm the identity of the taxon. Ischnocnema guentheri is currently considered to be a species complex (Kwet \& Solé 2005, Gehara et al. 2013). Based on mitochondrial and nuclear sequences, combined with bioacoustic data, Gehara et al. (2013) identified I. guentheri sensu stricto as a lineage restricted to the PNT, although it seems likely that this form is also present in adjacent areas.

Overall, only six of the species recorded in the PNT (Allobates olfersioides, Cycloramphus eleutherodactylus, Scinax trapicheiroi, Thoropa lutzi, Vitreorana eurygnatha, and V. uranoscopa) are listed under some category of extinction threat (Bergallo et al. 2000, ICMBIO 2018, IUCN 2020), although the populations of 15 species are thought to be declining (IUCN 2020). Of these six species, we recorded only 
Table 3. The species richness $(\mathrm{S})$ of amphibians recorded in forest remnants in the state of Rio de Janeiro, Brazil. The information provided is: location, municipality, sampling period, total effort employed in the visual survey (VES, in hours), quadrat ( $\mathrm{m}^{2}$ ), and pitfall trap methods (with the bucket volume in liters), other methods or sources used (OMS), and the respective reference. * Information on sampling period or effort was not available. PNM = Parque Natural Municipal, RPPN = Reserva Particular do Patrimônio Natural. In the pitfall trap column, BD = bucketdays, $\mathrm{BH}=$ bucket-hours. Other methods/sources included zoological collections [CC1 = Centro de Primatologia do Rio de Janeiro (CPRJ), CC2 = Coleção de Anfíbios da Universidade Federal do Estado do Rio de Janeiro (UNIRIO), CC3 = Coleção Eugenio Izecksohn da Universidade Federal Rural do Rio de Janeiro (EI), CC4 = Coleção de Anfíbios do Museu Nacional (MNRJ), CC5 = Coleção de Anfíbios do Departamento de Zoologia da Universidade Federal do Rio de Janeiro (ZUFRJ)], acoustic searches (AS), funnel traps for tadpoles (FT), tube traps (TT), and Management Plan (MP)

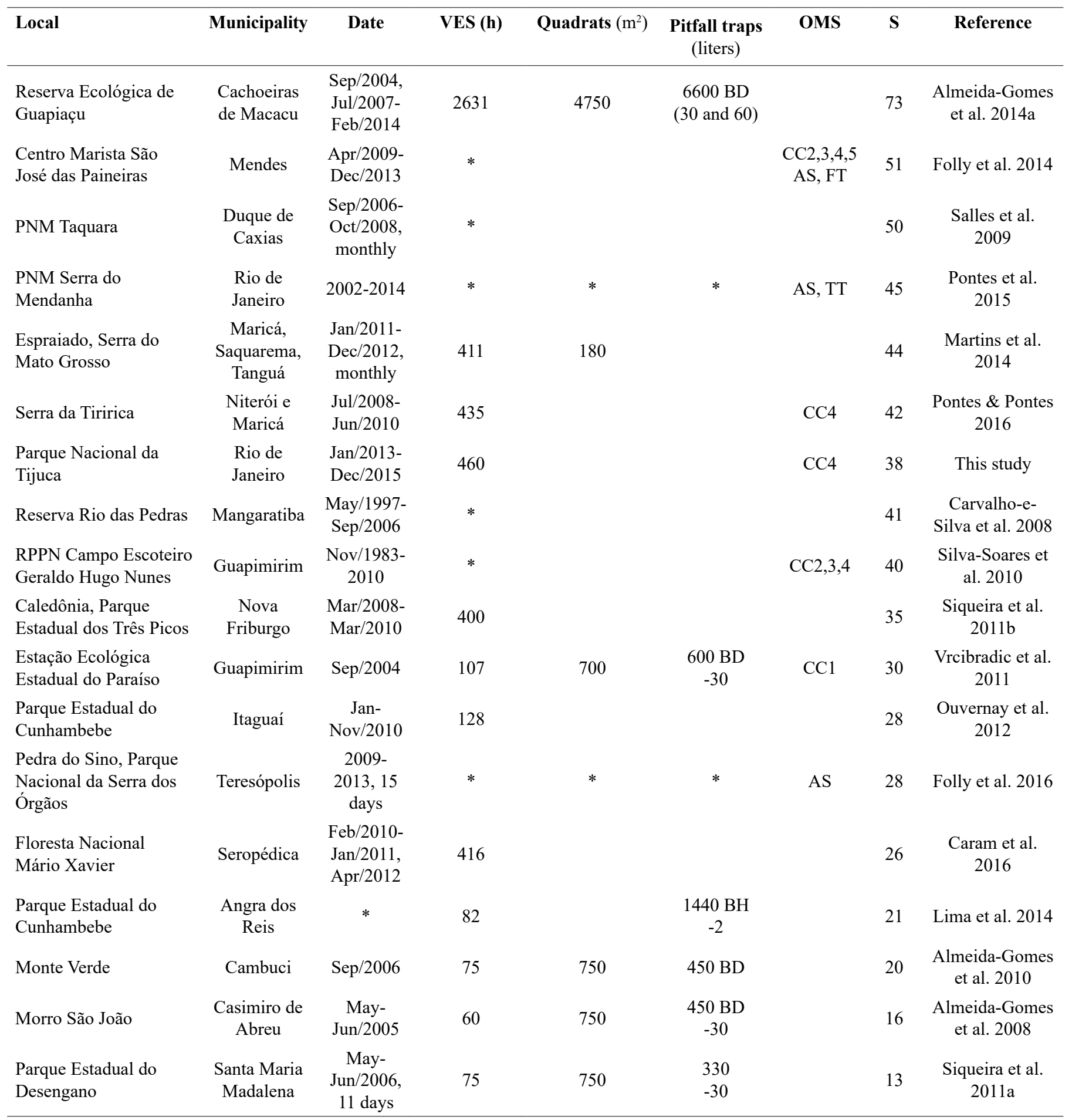


one, S. trapicheiroi, during our field surveys. However, although $S$. trapicheiroi is listed as Near Threatened by the IUCN due to its greatly reduced area of occurrence of less than $20,000 \mathrm{~km}^{2}$ (Rodrigues \& Carvalho-e-Silva 2004), it is assigned to the Least Concern category in the Brazilian red list (ICMBIO 2018). Verdade and Rodrigues (2007) allocated three other specific names for geographically widespread populations into synonymy of Allobates olfersioides (Lutz, 1925): A. alagoanus (Bokermann, 1967), A. capixaba (Bokermann, 1967), and $A$. carioca (Bokermann, 1967). According to this arrangement, $A$. olfersioides is widely distributed along much of the eastern coast of Brazil, between Rio de Janeiro and the state of Alagoas, 2,000 km to the north. However, Haddad et al. (2013) still considered these disconnected populations as different species: A. olfersioides in the state of Rio de Janeiro, A. capixaba in the states of Espírito Santo, and A. alagoanus in the state of Alagoas. The clarification of whether these populations are distinct species or lineages of the same species is essential (Forti et al. 2017). In their assessment of the conservation status of this amphibian, Haddad et al. (2016) considered only A. carioca to be a synonym of $A$. olfersioides, which restricted the species distribution to the metropolitan region of Rio de Janeiro. In this case, the reduction of the area of occurrence of the taxon to approximately $7,730 \mathrm{~km}^{2}$, the lack of records from some localities, including the PNT, over the past 30 years, and the loss of habitat quality over this period has led to the classification of this species as Vulnerable in both the Brazilian red list (ICMBIO 2018) and that of the IUCN (2020).

Thoropa lutzi is classified as Endangered by the IUCN (2020), but as Data Deficient in Brazil (ICMBIO 2018). This species is known to occur only in the states of Rio de Janeiro and Espírito Santo. Populations have not been observed in Rio de Janeiro over the past 30 years, however, including PNT (Sabbag et al. 2018). The other three species, Cycloramphus eleutherodactylus, Vitreorana eurygnatha, and V. uranoscopa, are listed only at the state level (Bergallo et al. 2000), as Presumably Threatened, and only C. eleutherodactylus is listed by the IUCN (2020), as Data Deficient. Cycloramphus eleutherodactylus is known to occur in the Brazilian states of Paraná, São Paulo, Rio de Janeiro, and Minas Gerais (Rossa-Feres et al. 2017, Santos-Pereira et al. 2018), although some studies have reported its disappearance by the beginning of the 20th century (Izecksohn \& Carvalho-e-Silva 2001, Eterovick et al. 2005). We did not collect $C$. eleutherodactylus during fieldwork and it has not been found at PNT since 1972 (Matos 2011). Nevertheless, Lima et al. (2012) concluded that this species may be relatively abundant in some cave environments, and emphasized the importance of including these habitats in amphibian inventories.

Hylodidae species of three genera, Crossodactylus, Hylodes and Megaelosia, are rheophilic and endemic to the Atlantic Forest (Laia \& Rocha 2012), where they are typically found in well-preserved forest fragments (e.g., Santos-Pereira et al. 2016, Malagoli et al. 2017). These species are strongly associated with this type of environment, and depend on streams throughout their life cycle (eggs, tadpoles, and adults), being thus vulnerable to the loss of riparian forest (AlmeidaGomes et al. 2014b). These anurans are particularly relevant to conservation initiatives, given that their effective area of occupation is normally restricted to water courses, a minor fraction of the total area of most forests, which makes them especially vulnerable to extinction (Almeida-Gomes et al. 2014b).
Only one of the reptiles recorded in the present study, the tortoise Chelonoidis denticulatus, is considered to be under some threat of extinction, being classified as Vulnerable by the IUCN (2020), although it is considered to be Least Concern in Brazil (ICMBIO 2018). The occurrence of Chelonoidis denticulatus was recorded in the Atlantic Forest of Rio de Janeiro in 1820 by Prince Maximilian zu WiedNeuwied, who found carapaces of this species on the sandy plains in the north of the municipality of Cabo Frio (Vanzolini 1994, VargasRamírez et al. 2010, Vanzolini \& Myers 2015). While C. denticulatus was originally recorded in the Atlantic Forest, it appears to have been eradicated subsequently from the forests of eastern Brazil (Vanzolini $\&$ Myers 2015). This species is being reintroduced into the PNT by the Refauna Project (Refauna 2019).

One important question that has yet to be answered regards the original occurrence of the tortoise Chelonoidis carbonarius in the state of Rio de Janeiro. This species was originally described by Spix (1824) from specimens obtained from the region of the Amazon River. Pritchard and Trebbau (1984), Vanzolini (1994), Ernst and Leuteritz (1999) and Vargas-Ramírez et al. (2010) described the geographic distribution of the species in Brazil, and in particular, indicated its absence in the state of Rio de Janeiro. While a number of studies have indicated the presence (e.g., Rocha et al. 2004, Köhler 2008) or possible occurrence (Tozetti et al. 2017) of C. carbonarius in Rio de Janeiro, it is difficult to establish whether this region was part of the original distribution of the species, or whether its occurrence in the region (if confirmed) is due to the deliberate release into the wild of animals raised as pets or for food.

Two of the species of the herpetofauna recorded in the PNT Hemidactylus mabouia and Trachemys scripta - are exotic invaders. The house gecko, H. mabouia, was originally introduced into Brazil from Africa during the colonial period, and has since expanded its area of distribution considerably in the country's natural environments (Rocha \& Bergallo 2011, Telles et al. 2015, Oliveira et al. 2016, Winck et al. 2017). Hemidactylus mabouia was observed in the built-up areas of the PNT, which is typical of its occurrence at other localities (Rocha et al. 2011, Oliveira et al. 2016). The presence of this lizard in the vicinity of the park's natural habitats demands special attention due to the potential for the species to become invasive (Rocha et al. 2011).

The pond slider, Trachemys scripta, was originally found in the southern United States and northern Mexico, but since the 1970s, large numbers have been raised in the United States for the pet trade, and this resulted in the introduction of the species in many places around the world (e.g., Ramsay et al. 2007, van Dijk et al. 2011). The presence of T. scripta in natural environments has negative impacts on the native freshwater turtles (e.g., Cadi \& Joly 2004, Hidalgo-Vila et al. 2009). Trachemys scripta has been recorded in disturbed areas within the PNT, probably as the result of intentional release of animals raised as pets. It is still unclear whether this exotic species has established a viable population in the state of Rio de Janeiro (Oliveira et al. 2020).

A number of amphibian and reptile species of interest occur in the PNT, including those endemics to either the Atlantic Forest or to Rio de Janeiro state and/or municipality, those under some threat of extinction, and those with declining populations. The presence of all those taxa reinforces the importance of the park for the conservation of the region's herpetofauna. The considerable diversity of reptiles and amphibians found in the PNT also testifies to the success of the reforestation program of this protected area, which now provides an important refuge for 
species of both groups. The results of our inventory, which recorded a total of 74 species, constitute the first comprehensive published overview of the composition and abundance of the herpetofauna of the Parque Nacional da Tijuca.

\section{Supplementary Material}

The following online material is available for this article:

Appendix 1 - Voucher specimens of amphibians and reptiles from the Parque Nacional da Tijuca deposited at the Museu Nacional, Rio de Janeiro (MNRJ).

Appendix 2- List of species of amphibians and reptiles recorded from herpetological collections, and respective voucher numbers, from Parque Nacional da Tijuca, Rio de Janeiro, Brazil.

\section{Acknowledgments}

This research was supported by grants from Conselho Nacional de Desenvolvimento Científico e Tecnológico (CNPq - processes, 302974/2015-6, 424473/2016-0 and 304375/2020-9) and from Fundação Carlos Chagas Filho de Amparo à Pesquisa do Estado do Rio de Janeiro (FAPERJ - processes E-26/102.765.2012, E-26/202.920/2015 and E-26/202.803/2018) through the "Programa Cientistas do Nosso Estado" to CFDR. TAD received a postdoctoral grant from Coordenação de Aperfeiçoamento de Pessoal de Nível Superior (CAPES). CCS (Process E-26/202.477/2019), JCFO (Process E-26/202.388/2017), LAF (Process E-26/202.775/2016) and MSP (Process E-26/202.297/2019) thanks FAPERJ for the postdoctoral fellowships and MAS (Process E-26/202.180/2019) thanks FAPERJ for the TCT fellowships. The specimens were collected under permit \#33309-4 and \#17474-1, granted by the Instituto Chico Mendes de Conservação da Biodiversidade (ICMBio). We thank S. Ferrari and D. Vrcibradic for review and suggestions. We are grateful to colleagues from MNRJ who provided secondary data from PNT: J. P. Pombal Jr and M. W. Cardoso (amphibians); P. Passos and P. Pinna (reptiles).

\section{Author Contributions}

Thiago Arnt Dorigo: Substantial contribution in the concept and design of the study; contribution to data collection; contribution to data analysis and interpretation; contribution to manuscript preparation; contribution to critical revision, adding intellectual content.

Carla Costa Siqueira: Substantial contribution in the concept and design of the study; contribution to data analysis and interpretation; contribution to manuscript preparation; contribution to critical revision, adding intellectual content.

Jane C. F. Oliveira: Substantial contribution in the concept and design of the study; contribution to data analysis and interpretation; contribution to manuscript preparation; contribution to critical revision, adding intellectual content.

Luciana Ardenghi Fusinatto: Substantial contribution in the concept and design of the study; contribution to manuscript preparation; contribution to critical revision, adding intellectual content.

Manuela Santos-Pereira: Substantial contribution in the concept and design of the study; Contribution to data analysis and interpretation; contribution to manuscript preparation; contribution to critical revision, adding intellectual content.

Marlon Almeida-Santos: Substantial contribution in the concept and design of the study; contribution to data analysis and interpretation; contribution to manuscript preparation; contribution to critical revision, adding intellectual content.

Thiago Maia-Carneiro: Contribution to data collection.

Caroline N. C. Reis: Contribution to data collection.

Carlos Frederico Duarte Rocha: Substantial contribution in the concept and design of the study; contribution to data analysis and interpretation; contribution to manuscript preparation; contribution to critical revision, adding intellectual content.

\section{Conflicts of Interest}

The authors declare that they have no conflict of interest related to the publication of this manuscript.

\section{References}

ABREU, R.C.R. \& RODRIGUES, P.J.F. 2010. Exotic tree Artocarpus heterophyllus (Moraceae) invades the Brazilian Atlantic Rainforest. Rodriguésia 61: 677-688.

ALLMON, W.D. 1991. A plot study of forest floor litter frogs, Central Amazon, Brazil. J. Trop. Ecol. 7(4): 503-522.

ALMEIDA-GOMES, M. \& ROCHA, C.F.D. 2014. Diversity and distribution of lizards in fragmented Atlantic Forest landscape in Southeastern Brazil. 2014. J. Herpetol. 48(3): 423-429.

ALMEIDA-GOMES, M., VRCIBRADIC, D., SIQUEIRA, C.C., KIEFER, M.C., KLAION, T., ALMEIDA-SANTOS, P., NASCIMENTO, D., ARIANI, C.V., BORGES-JR., V.N.T., FREITAS-FILHO, R.F., VAN SLUYS, M. \& ROCHA, C.F.D. 2008. Herpetofauna of an Atlantic Rainforest area (Morro São João) in Rio de Janeiro State, Brazil. An. Acad. Bras. Cienc. 80(2): 291-300.

ALMEIDA-GOMES, M., ALMEIDA-SANTOS, M., GOYANNES-ARAÚJO, P., BORGES-JR,V.N.T., VRCIBRADIC, D., SIQUEIRA, C.C., ARIANI, C.V., DIAS, A.S., SOUZA, V.V., PINTO, R.R., VAN SLUYS, M. \& ROCHA, C.F.D. 2010. Anurofauna of an Atlantic Rainforest fragment and its surroundings in northern Rio de Janeiro State, Brazil. Braz. J. Biol. 70(3):871-877.

ALMEIDA-GOMES, M., SIQUEIRA, C.C., BORGES-JR, V.N.T., VRCIBRADIC, D., FUSINATTO, L.A. \& ROCHA, C.F.D. 2014a. Herpetofauna of the Reserva Ecológica de Guapiaçu (REGUA) and its surrounding areas, in the state of Rio de Janeiro, Brazil. Biota Neotrop. 14(3): 1-15. http://www.biotaneotropica.org.br/v14n3/pt/ fullpaper?bn00714032014+en (last accessed on 02/11/2020).

ALMEIDA-GOMES, M., LORINI, M.L., ROCHA, C.F.D. \& VIEIRA, M.V. 2014b. Underestimation of extinction threat to stream-dwelling amphibians due to lack of consideration of narrow area of occupancy. Conserv. Biol. 28(2): 616-619.

BERGALLO, H.G., ROCHA, C.F.D., ALVES, M.A.S. \& VAN SLUYS, M. 2000. A fauna ameaçada de extinção do Estado do Rio de Janeiro. EdUERJ, Rio de Janeiro.

BRASIL. 1961. Decreto No 50.923, de 06 de julho de 1961. Diário Oficial da União, Brasília, Seção 1, p. 6132, 06 jul. 1961. Available online at: https:// www2.camara.leg.br/legin/fed/decret/1960-1969/decreto-50923-6-julho1961-391130-publicacaooriginal-1-pe.html (accessed on 12/09/2019).

CADI, A. \& JOLY, P. 2004. Impact of the introduction of the red-eared slider (Trachemys scripta elegans) on survival rates of the European pond turtle (Emys orbicularis). Biodivers. Conserv. 13(13): 2511-2518.

CANEDO, C.C. 2008. Revisão taxonômica de Hylodes Fitzinger, 1826 (Anura, Hylodidae). Tese de Doutorado. Museu Nacional/UFRJ, Rio de Janeiro. 
CARAM, J., GOMES, M.R., LUNA-DIAS, C. \& CARVALHO-E-SILVA, S.P. 2016. Updated list of anurans from Floresta Nacional Mário Xavier, Seropédica, Rio de Janeiro, Brazil: Changes from 1990 to 2012. Check List 12(6): 1-7.

CARVALHO-E-SILVA, A.M.P.T., SILVA, G.R. \& CARVALHO-E-SILVA, S.P. 2008. Anuros da Reserva Rio das Pedras, Mangaratiba, RJ, Brasil. Biota Neotrop. 8(1): 199-209. http://www.biotaneotropica.org.br/v8n1/pt/ fullpaper?bn02608012008+pt (last accessed on 02/11/2020).

CARVALHO-E-SILVA, S.P., CARVALHO-E-SILVA, A.M.P.T. \& IZECKSOHN, E. 2008. Amphibia. Plano de Manejo do Parque Nacional da Tijuca. v. 1. ICMBIO/MMA, Brasília, p. 198-200.

COELHO NETTO, A.L. 2005. A interface florestal-urbana e os desastres naturais relacionados à água no maciço da Tijuca: desafios ao planejamento urbano numa perspectiva sócio-ambiental. Rev. Dep. Geogr. 16: 46-60.

COIMBRA-FILHO, A.D., ALDRIGHI, A.D. \& MATINS, H.F. 1973. Nova contribuição ao restabelecimento da fauna do Parque Nacional da Tijuca. Brasil Florestal 4(16): 7-25.

COLWELL, R.K. 2009. EstimateS: Statistical estimation of species richness and shared species from samples. version 8.2. User's Guide and application. Available online at: http://purl.oclc.org/estimates

COLWELL, R.K., MAO, C. X. \& CHANG, J. 2004. Interpolating, extrapolating, and comparing incidence-based species accumulation curves. Ecology 85: 2717-2727.

COSTA, H.C. \& BÉRNILS, R.S. 2018. Répteis do Brasil e suas Unidades Federativas: Lista de espécies. Herpetol. Brasil. 8(1): 11-57.

CRUMP, M.L. 1971. Quantitative analysis of the ecological distribution of a tropical herpetofauna. Occ. Pap. Mus. Nat. Hist. Univ. Kansas 3:1-62.

CRUMP, M.L. \& SCOTT-JR., N.J. 1994. Visual encounter surveys. In measuring and monitoring biological diversity: Standard methods for amphibians (W.R. Heyer, M.A. Donnelly, R.W. McDiarmid, L.A.C. Hayek \& M.S. Foster, eds.). Smithsonian Institution Press, Washington, p. 84-92.

CRUZ, A.J.R., DRUMMOND, L.O., LUCENA, V.D., MAGALHÃES, A.D., BRAGA, C.A.C., ROLIN, J.M. \& PIRES, M.R.S. 2014. Lizard fauna (Squamata, Sauria) from Serra do Ouro Branco, Southern Espinhaço Range, Minas Gerais, Brazil. Check List 10(6): 1290-1299.

CRUZ, C.A.G., CARAMASCHI, U., FUSINATTO, L.A. \& BRASILEIRO, C.A. 2019. Taxonomic review of Dendrophryniscus brevipollicatus Jiménez de la Espada, 1870, with revalidation of D. imitator (Miranda-Ribeiro, 1920) and D. lauroi Miranda-Ribeiro, 1926, and description of four new related species (Anura, Bufonidae). Zootaxa 4648: 27-62.

DIXO, M. \& VERDADE, V.K. 2006. Herpetofauna de serrapilheira da Reserva Florestal de Morro Grande, Cotia (SP). Biota Neotrop. 6(2): 11-20. http:// www.biotaneotropica.org.br/v6n2/pt/fullpaper?bn00806022006+pt (last accessed on $02 / 11 / 2020$ ).

DONNELLY, M.A. 1994. Amphibian diversity and natural history. In La Selva: Ecology and natural history of a Neotropical rainforest (L.A. McDade, K.S. Bawa, H.A. Hespenheide \& G.S. Hartshorn, eds). University of Chicago Press, Chicago, p. 199-209.

DORIGO, T.A., VRCIBRADIC, D., BORGES-JR., V.N.T. \& ROCHA, C.F.D. 2014. New records of anuran predation by snakes of the genus Thamnodynastes Wagler, 1830 (Colubridae: Dipsadinae) in the Atlantic rainforest of southeastern Brazil. Herpetol. Notes 7: 261-264.

DORIGO, T.A., VRCIBRADIC, D. \& ROCHA, C.F.D. 2018. The amphibians of the state of Rio de Janeiro, Brazil: an updated and commented list. Pap. Avulsos Zool. 58: e20185805

DUELLMAN, W.E. 1988. Patterns of species diversity in anuran amphibians in the American Tropics. Ann. Missouri Bot. Gard. 75: 79-104.

ERNST, C.H. \& LEUTERITZ, T.E.J. 1999. Geochelone denticulata. Catalogue of American Amphibians and Reptiles 691: 1-6.

ETEROVICK, P.C., CARNAVAL, A.C.O.Q., BORGES-NOJOSA, D.M., SILVANO, D.L., SEGALLA, M.V. \& SAZIMA, I. 2005. Amphibian declines in Brazil: An overview. Biotropica 37(2): 166-179.
FOLLY, M., KIRCHMEYER, J., GOMES, M.R., HEPP, F., RUGGERI, J., LUNA-DIAS, C., BEZERRA, A.M., AMARAL, L.C. \& CARVALHOE-SILVA SP. 2014. Amphibians from the Centro Marista São José das Paineiras, in Mendes, and surrounding municipalities, State of Rio de Janeiro, Brazil. Herpetol. Notes 7: 489-499.

FOLLY, M., BEZERRA, A.M., RUGGERI, J., HEPP, F., CARVALHO-ESILVA, A.M.P.T., GOMES, M.R. \& CARVALHO-E-SILVA S.P. 2016. Anuran fauna of the high-elevation areas of the Parque Nacional da Serra dos Órgaos (PARNOSA), southeastern Brazil. Oecol. Australis 20(2): 247-258.

FORTI, L.R., SILVA, T.R.A. \& TOLEDO, L.F. 2017. The acoustic repertoire of the Atlantic Forest Rocket Frog and its consequences for taxonomy and conservation (Allobates, Aromobatidae). ZooKeys 692: 141-153.

FROST, D.R. 2020. Amphibian Species of the World: an Online Reference. Version $6.0(02 / 11 / 2020)$. Electronic Available online at: http://research. amnh.org/herpetology/amphibia/index.html (accessed on 01/06/2020). American Museum of Natural History, New York.

GEHARA, M., CANEDO, C., HADDAD, C.F.B. \& VENCES, M. 2013. From widespread to microendemic: Molecular and acoustic analyses show that Ischnocnema guentheri (Amphibia: Brachycephalidae) is endemic to Rio de Janeiro, Brazil. Conserv. Genet. 14(5): 973-982.

GRAZZIOTIN, F.G., ZAHER, H., MURPHY, R.W., SCROCCHI, G., BENAVIDES, M.A., ZHANG, Y.P. \& BONATTO, S.L. 2012. Molecular phylogeny of the New World Dipsadidae (Serpentes: Colubroidea): A reappraisal. Cladistics 28(5): 437-459.

GUARABYRA, B., BEZERRA, A.M., GALVÃO, A. \& CARVALHO-E-SILVA, S.P. 2020. First record of Ostracod ingestion by adult frogs. Cuadernos de Herpetología 34(1): 103-105.

HADDAD, C.F.B. \& PRADO, C.P.A. 2005. Reproductive modes in frogs and their unexpected diversity in the Atlantic forest in Brazil. BioScience $55: 207-217$.

HADDAD, C.F.B., TOLEDO, L.F., PRADO, C.P.A., LOEBMANN, D., GASPARINI, J.L. \& SAZIMA, I. 2013. Guia dos anfíbios da Mata Atlântica: Diversidade e biologia. Anolis Books, São Paulo.

HADDAD, C.F.B., SEGALLA, M.V., BATAUS, Y.S.L., UHLIG, V.M., BATISTA, F.R.Q., GARDA, A., HUDSON, A.A., CRUZ, C.A.G., STRÜSMANN, C., BRASILEIRO, C.A., SILVANO, D.L., NOMURA, F., PINTO, H.B.A., AMARAL, I.B., GASPARINI, J.L.R., LIMA, L.P., MARTINS, M.R.C., HOOGMOED, M.S., COLOMBO, P., VALDUJO, P.H., GARCIA, P.C.A., FEIO, R.N., BRANDÃO, R.A., BASTOS, R.P. \& CARAMASCHI, U. 2016. Avaliação do Risco de Extinção de Thoropa lutzi Cochran, 1938. Processo de avaliação do risco de extinção da fauna brasileira. ICMBio. Available online at: http://www.icmbio.gov.br/ portal/faunabrasileira/estado-de-conservacao/7812-anfibios-thoropa-lutzi (accessed on 01/10/2020).

HAMMER, O., HARPER, D.A.T. \& RYAN, P.D. 2001. PAST: Paleontological Statistics software package for education and data analysis. Paleontol. Electron. 4:1-9.

HEDGES, S.B., COULOUX, A. \& VIDAL, N. 2009. Molecular phylogeny, classification, and biogeography of West Indian racer snakes of the Tribe Alsophiini (Squamata, Dipsadidae, Xenodontinae). Zootaxa 2067: 1-28.

HEPP, F. \& CARVALHO-E-SILVA, S.P. 2011. Description and comparison of advertisement calls of Euparkerella brasiliensis (Parker, 1926) and E. cochranae Izecksohn, 1988 (Amphibia: Anura: Strabomantidae). Herpetol. Notes 4: 45-51.

HEPP, F., LOURENCO, A.C.C. \& POMBAL JR., J.P. 2017. Bioacoustics of four Scinax species and a review of acoustic traits in the Scinax catharinae species group (Amphibia: Anura: Hylidae). Salamandra 53: 212-230.

HEYER, W.R. 1973. Systematics of the marmoratus group of the frog genus Leptodactylus (Amphibia, Leptodactylidae): Contributions in Science. Nat. Hist. Mus. Los Angeles County 251: 1-50.

HEYER, W., RAND, A., CRUZ, C., PEIXOTO, O. \& NELSON, C. 1990. Frogs of Boracéia. Arq. Zool. 31(4): 231-410. 
HIDALGO-VILA, J., DÍAZ-PANIAGUA, C., RIBAS, A., FLORENCIO, M., PÉREZ-SANTIGOSA, N. \& CASANOVA, J.C. 2009. Helminth communities of the exotic introduced turtle, Trachemys scripta elegans in southwestern Spain: Transmission from native turtles. Res Vet Sci 86(3): 463-465.

HOOGMOED, M.S., FERNANDES, R., KUCHARZEWSKI, C., MOURALEITE, J.C., BÉRNILS, R.S., ENTIAUSPE-NETO, O.M. \& RÊGOS DOS SANTOS, F.P. 2019. Synonymization of Uromacer ricardinii Peracca, 1897 with Dendrophis aurata Schlegel, 1837 (Reptilia: Squamata: Colubridae: Dipsadinae), a rare South American snake with a disjunct distribution. S. Am. J. Herpetol. 14(2): 88-102.

ICMBIO. 2008. Plano de manejo do Parque Nacional da Tijuca. ICMBIO/ MMA, Brasília.

ICMBIO. 2018. Livro vermelho da fauna brasileira ameaçada de extinção. V 1 , 1. ed. ICMBio/MMA, Brasília.

IUCN. 2020. The IUCN red list of threatened species. Version 2019-3. Available online at: http://www.iucnredlist.org (accessed on 01/10/2020).

IZECKSOHN, E. \& CARVALHO-E-SILVA, S.P. 2001. Anfíbios do município do Rio de Janeiro. Editora UFRJ, Rio de Janeiro.

KÖHLER, G. 2008. Reptiles of Central America. 2. ed. Herpeton, Offenback.

KREBS, C.J. 1999. Ecological methodology. Harper \& Row, New York.

KWET, A. \& SOLÉ, M. 2005. Validation of Hylodes henselii Peters, 1870, from southern Brazil and description of acoustic variation in Eleutherodactylus guentheri (Anura: Leptodactylidae). J. Herpetol. 39(4): 521-532.

LAIA, R.C. \& ROCHA, C.F.D. 2012. Adults and tadpoles of species of Hylodidae (Anura): History and taxonomy perspectives. Zoologia 29(1): 89-94.

LIMA, A., ARAUJO, C. \& VERDADE, V. 2012. Cycloramphus eleutherodactylus (Alto Button Frog): Calling among rocks and caves. Herpetol. Bull. 120: 41-42.

LINGNAU, R., CANEDO, C. \& POMBAL JR., J.P. 2008. A new species of Hylodes Fitzinger 1826 (Anura: Hylodidae) from the Brazilian Atlantic Forest. Copeia 2008: 595-602.

MACHADO, A.O., WINCK, G., DORIGO, T.A. \& ROCHA, C.F.D. 2016. Diet, diel activity pattern, habitat use, and reproductive effort of Hylodes nasus (Anura: Hylodidae) in one of the world's largest urban parks (Tijuca National Park), Southeastern Brazil. S. Am. J. Herpetol. 11(2): 127-135.

MACIEL, A.O., CASTRO, T.M., STURARO, M.J., COSTA SILVA, I.E., FERREIRA, J.G., SANTOS, R., RISSE-QUAIOTO, B., BARBOZA, B.A., OLIVEIRA, J.C.F., SAMPAIO, I. \& SCHNEIDER, H. 2019. Phylogenetic systematics of the Neotropical caecilian amphibian Luetkenotyphlus (Gymnophiona: Siphonopidae) including the description of a new species from the vulnerable Brazilian Atlantic Forest. Zool. Anz. 281: 76-83.

MAGURRAN, A.E. 2004. Measuring biological diversity. Blackwell Science, Oxford.

MAGURRAN, A.E. \& MCGILL, B.J. 2011. Biological diversity: Frontiers in measurement and assessment. Oxford University Press, Oxford.

MALAGOLI, L.R., DE SÁ, F.P., CANEDO, C. \& HADDAD, C.F. 2017. A new species of Hylodes (Anura, Hylodidae) from Serra do Mar, southeastern Brazil: The fourth with nuptial thumb tubercles. Herpetologica 73(2): 136-147.

MARQUES, O.A.V. \& SAZIMA, I. 2004. História natural dos répteis da Estação Ecológica Juréia-Itatins. In Estação Ecológica Juréia-Itatins: Ambiente físico, flora e fauna (O.A.V. Marques \& W. Duleba, eds). Holos Editora, Ribeirão Preto, p. 257-277.

MARTINS, A., PONTES, R., MATTEDI, R., MURTA-FONSECA, R.A., FRATANI, J., RAMOS, L.O., BRANDÃO, A.L.R., MACIAL, D.B. \& PINTO, R.R. 2019. Herpetofauna community from coastal restinga remnants in Northeast Rio de Janeiro state, Brazil. J. Coast. Conservat. 23(6): 1019-1037.

MATOS, L.D. 2011. Revisão taxonômica das espécies de Cycloramphus do grupo eleutherodactylus (Anura, Cycloramphidae). Dissertação de Mestrado, Universidade de São Paulo, São Paulo.

MENIN, M., CARVALHO, V.T., ALMEIDA, A.P., GORDO, M., OLIVEIRA, D.P., LUIZ, L.F., CAMPOS, J. \& HRBEK, T. 2017. Amphibians from Santa Isabel do Rio Negro, Brazilian Amazonia. Phyllomedusa 16(2): 183-199.

MOCELIN, M.A.O. 2008. Répteis. In: Plano de Manejo do Parque Nacional da Tijuca. v. 1. ICMBIO/MMA, Brasília, 200-201.
MYERS, N., MITTERMEIER, R.A., MITTERMEIER, C.G., FONSECA, G.A. \& KENT, J. 2000. Biodiversity hotspots for conservation priorities. Nature 403(6772): 853-858.

NASCIMENTO, L.B., POMBAL JR., J.P. \& HADDAD, C.F.B. 2001. A new frog of the genus Hylodes (Amphibia: Leptodactylidae) from Minas Gerais, Brazil. J. Zool. 254(4): 421-428.

OLIVEIRA, J.C.F., GONZALEZ, R.C., PASSOS, P., VRCIBRADIC, D. \& ROCHA, C.F.D. 2020. Non-avian reptiles of the state of Rio de Janeiro, Brazil: Status of knowledge and commented list. Pap. Avulsos Zool. 60: e20206024.

OLIVEIRA, J.C.F., WINCK, G.R., PEREIRA-RIBEIRO, J. \& ROCHA, C.F.D. 2016. Antropogenic effect or niche preference? Contributions to the knowledge of Hemidactylus mabouia invasion in South America. NorthWest J. Zool 12(2): 389-392.

OLIVEIRA, U., SOARES-FILHO, B.S., SANTOS, A.J., PAGLIA, A.P., BRESCOVIT,A.D., CARVALHO, C.J.B., SILVA, D.P., REZENDE, D.T., LEITE, F.S.F., BATISTA, J.A.N., BARBOSA, J.P.P.P., STEHMANN, J.R.,ASCHER, J.S., VASCONCELOS, M.F., MARCO, P., LÖWENBERG-NETO, P. \& FERRO, VG 2019. Modelling highly biodiverse areas in Brazil. Sci. Rep. 9(6355).

OUVERNAY, D., FIUZA, L.M.S.C., BARBOSA, T.R., ALBUQUERQUE, I.G.L.C. \& ARAUJO, A.F.B. 2012. Amphibia, Anura, Parque Estadual do Cunhambebe, Itaguaí municipality, Rio de Janeiro state. Check List 8(6): 1047-1051.

PADIAL, J.M., GRANT, T. \& FROST, D.R. 2014. Corrections to "Padial et al. (2014) Molecular systematics of terraranas (Anura: Brachycephaloidea) with an assessment of the effects of alignment and optimality criteria". Zootaxa 3827(4): 599-600.

PATTO, C.E.G. \& PIE, M.R. 2001. Notes on the population dynamics of Hylodes asper in Southeastern Brazil (Anura: Leptodactylidae). J. Herpetol. 35(4): 684-686.

POE, S., NIETO-MONTES DE OCA, A., TORRES-CARVAJAL, O., DE QUEIROZ, K., VELASCO, J.A., TRUETT, B., GRAY, L.N., RYAN, M.J., KÖHLER, G., AYALA-VARELA, F. \& LATELLA, I. 2017. A phylogentic, biogeographic, and taxonomic study of all extant species of Anolis (Squamata; Iguanidae). Syst. Biol. 66(5): 663-697.

POMBAL JR., J.P. \& HADDAD, C.F.B. 2007. Estratégias e modos reprodutivos em anuros. In: Herpetologia no Brasil II (L.B. Nascimento \& P.M.E. Oliveira, eds.). Sociedade Brasileira de Herpetologia, Belo Horizonte, p. 101-116.

PONTES, R. \& PONTES, J.A.L. 2016. Anfíbios da Serra da Tiririca: Diversidade e conservação. In: Biodiversidade e sociedade no Leste Metropolitano do Rio de Janeiro (M.G. Santos, org.). v. 1, 1. ed. Editora da Universidade do Estado do Rio de Janeiro, Rio de Janeiro, p. 19-68.

PONTES, J.A.L., PONTES, R.C., ROCHA, R.F., LINDENBERG, P.M., SILVA, K.P., SANTOS, W.A., LEMOS, N.A., HASSAS, P.G.A., ALVEZ, A.O., LOPES, L.F.B.A., PERRO, L.C.T., BOLDRINI, A.P., NUNES, E.C.F., COSTA, L.F., KISLING, R.W. \& ROCHA, C.F.D. 2015. Unidades de Conservação da cidade do Rio de Janeiro: Hotspots da herpetofauna carioca. In: Biodiversidade carioca: segredos revelados (J.A.L. Pontes, org.). 1. ed. Technical Books Editora, Rio de Janeiro, p. 176-194.

PONTES, J.A.L., PONTES, R.C. \& ROCHA, C.F.D. 2009. The snake community of Serra do Mendanha, in Rio de Janeiro State, southeastern Brazil composition, abundance, richness and diversity in areas with different conservation degrees. Braz. J. Biol. 69(3): 795-804.

PRATES, I., MELO-SAMPAIO, P.R., QUEIROZ, K., CARNAVAL, A.C., RODRIGUES, M.T. \& OLIVEIRA DRUMMOND, L. 2019. Discovery of a new species of Anolis lizards from Brazil and its implications for the historical biogeography of montane Atlantic Forest endemics. Amphib-Reptilia 41: 87-103.

PRITCHARD, P.C.H. \& TREBBAU, P. 1984. The turtles of Venezuela. Society for the Study of Amphibians and Reptiles, Oxford.

RAMSAY, N.F., NG, P.K.A, O'RIORDAN, R.M. \& CHOU, L.M. 2007. The red-eared slider (Trachemys scripta elegans) in Asia: A review. In Biological invaders in inland waters: Profiles, distribution, and threats. Springer, Dordrecht, p. 161-174.

REFAUNA, PROJETO. 2019. Reintrodução de fauna e restabelecimento de interações na Mata Attântica. Available online at: https://refauna.wixsite. com/site (accessed on 02/12/2020). 
RIBEIRO, M.C., MARTENSEN, A.C., METZGER, J.P., TABARELLI, M., SCARANO, F. \& FORTIN, M. 2011. The Brazilian Atlantic Forest: A shrinking biodiversity hotspot. In: Biodiversity hotspots: Distribution and protection of conservation priority areas (F.E. Zachos \& J.C. Habel, eds.). Springer-Verlag, Heidelberg, p. 405-434.

ROCHA, C.F.D. 2017. O passado da Baía de Guanabara: Ecossistemas e biodiversidade. In: Baía de Guanabara: Passado, presente, futuros (D. Zee, R. Medeiros, F.R. Scarano \& I. Klabin (orgs.). 1ed. Andrea Jakobsson Estúdio Ltda, Rio de Janeiro, p. 40-61.

ROCHA, C.F.D. \& BERGALLO, H.G. 2011. Occurrence and distribution of the exotic lizard Hemidactylus mabouia Moreau de Jonnès, 1818 in Ilha Grande, RJ, Brazil. Rev. Bras. Biol. 71(2): 447-450.

ROCHA, C.F.D., VAN SLUYS, M., ALVES, M.A.S., BERGALLO, H.G. \& VRCIBRADIC, D. 2001. Estimates of forest floor litter frogs communities: A comparison of two methods. Austral Ecol. 26(1): 14-21.

ROCHA, C.F.D., BERGALLO, H.G., ALVES, M.A.S. \& VAN SLUYS, M. 2003. A biodiversidade nos grandes remanescentes florestais do Estado do Rio de Janeiro e nas restingas dos corredores da Mata Atlântica. 1. ed. Rima Editora, São Carlos.

ROCHA, C.F.D., BERGALlO, H.G., POMBAL JR., J.P., GEISE, L., VAN SLUYS, M., FERNANDES, R. \& CARAMASCHI, U. 2004. Fauna de anfibios, répteis e mamíferos do Estado do Rio de Janeiro, Sudeste do Brasil. Publ. Avulsos Mus. Nac. 104: 1-24.

ROCHA, C.F.D., ANJOS, L.A. \& BERGALLO, H.G. 2011. Conquering Brazil: The invasion by the exotic gekkonid lizard Hemidactylus mabouia (Squamata) in Brazilian natural environments. Zoologia 28(6): 747-754.

ROCHA, C.F.D., TELLES, F.B.S., VRCIBRADIC, D. \& COSTA, P. N. 2018. The herpetofauna from Ilha Grande (Angra dos Reis, Rio de Janeiro, Brazil): Updating species composition, richness, distribution and endemisms. Pap. Avulsos Zool. 58: 25-36.

RODRIGUES, M.T. \& CARVALHO-E-SILVA, A.M.T. 2004. Scinax trapicheiroi. The IUCN red list of threatened species 2004: e.T56001A11403446. https:// dx.doi.org/10.2305/IUCN.UK.2004.RLTS.T56001A11403446.en (accessed on $02 / 11 / 2020$ ).

ROSSA-FERES, D.D.C., GAREY, M.V., CARAMASCHI, U., NAPOLI, M.F., NOMURA, F., BISPO, A.A., BRASILEIRO, C.A., THOMÉ, M.T.C., SAWAYA, R.J., CONTE, C.E., CRUZ, C.A.G., NASCIMENTO, L.B., GASPARINI, J.L., ALMEIDA, A.D.P. \& HADDAD, C.F.B. 2017. Anfíbios da Mata Atlântica: Lista de espécies, histórico dos estudos, biologia e conservação. In: Revisões em zoologia: Mata Atlântica (E.L.A. Monteiro Filho \& C.E. Conte, orgs.). 1. ed. Ed. UFPR, Curitiba, p. 237-314.

SABBAG, A.F., LYRA, M.L., ZAMUDIO, K.R., HADDAD, C.F.B., FEIO, R.N., LEITE, F.S.F., GASPARINI, J.L. \& BRASILEIRO, C.A. 2018. Molecular phylogeny of Neotropical rock frogs reveals a long history of vicariant diversification in the Atlantic forest. Mol. Phylog. Evol. 122: 142-156.

SALLES, R.O.L., WEBER, L.N. \& SILVA-SOARES, T. 2009. Amphibia, Anura, Parque Natural Municipal da Taquara, municipality of Duque de Caxias, state of Rio de Janeiro, southeastern Brazil. Check List 5(4): 840-854.

SANTOS-PEREIRA, M., MILANI, D., BARATA-BITTENCOURT, L.F., IAPP, T.M. \& ROCHA, C.F.D. 2016. Anuran species of the Salto Morato Nature Reserve in Paraná, southern Brazil: Review of the species list. Check List 12(3): 1-11.

SANTOS-PEREIRA, M., POMBAL JR., J.P. \& ROCHA, C.F.D. 2018. Anuran amphibians in state of Paraná, southern Brazil. Biota Neotrop. 18(3): 1-19. http://www.biotaneotropica.org.br/v18n3/pt/fullpaper?bn00518032018+en (last accessed on 02/12/2020).

SEGALlA, M.V., CARAMASCHI, U., CRUZ, C.A.G., GARCIA, P.C.A., GRANT, T., HADDAD, C.F.B., SANTANA, D.J., TOLEDO, L.F. \& LANGONE, J.A. 2019. Lista de espécies brasileiras/Brazilian amphibians: List of species. Herpetol. Bras. 8(1): 65-96.

SILVA, F.R., LYRA, M.L., HADDAD, C.F.B. \& ROSSA-FERES, D.C. 2017. Expanding the knowledge about the occurrence of anurans in the highest amphibian diversity area of Atlantic Forest: Parque Estadual da Serra do Mar, São Paulo, Brazil. Biota Neotrop. 17(2): 1-13. http:// www.biotaneotropica.org.br/v17n2/pt/fullpaper?bn00817022017+en (last accessed on 02/12/2020).
SILVA-E-SOUZA, V.C., TAVARES, H.W. \& ABRUNHOSA, P.A. 2019. Influência de fatores ambientais e sociais sobre a atividade de vocalização de Hylodes nasus Lichtenstein (1823) (Amphibia, Anura) em um riacho na floresta da Tijuca, Rio de Janeiro, Brasil. Rev. Biol. Neotrop. 16(1): 9-18.

SILVA-SOARES, T., HEPP, F., COSTA, P.N., LUNA-DIAS, C., GOMES, M.R., CARVALHO-E-SILVA, A.M.P.T. \& CARVALHO-E-SILVA, S.P. 2010. Anfíbios anuros da RPPN Campo Escoteiro Geraldo Hugo Nunes, Município de Guapimirim, Rio de Janeiro, Sudeste do Brasil. Biota Neotrop. 10(2): 225-233. http://www.biotaneotropica.org.br/v10n2/pt/ fullpaper?bn01210022010+pt (last accessed on 02/12/2020).

SIQUEIRA, C.C., VRCIBRADIC, D., ALMEIDA-GOMES, M., MENEZES, V.A., BORGES-JUNIOR, V.N.T., HATANO, F.H., PONTES, J.A.L., GOYANNES-ARAÚJO, P., GUEDES, D.M., VAN SLUYS, M. \& ROCHA, C.F.D. 2011a. Species composition and density estimates of the anurofauna of a site within the northernmost large Atlantic Forest remnant (Parque Estadual do Desengano) in the state of Rio de Janeiro, Brazil. Biota Neotrop. 11(4): 131-137. http://www.biotaneotropica.org.br/v11n4/ pt/fullpaper?bn03311042011+en (last accessed on 02/12/2020).

SIQUEIRA, C.C., VRCIBRADIC, D., DORIGO, T.A. \& ROCHA, C.F.D. 2011 b. Anurans from two high-elevation areas of Atlantic Forest in the state of Rio de Janeiro, Brazil. Zoologia 28(4): 457-464.

SIQUEIRA, C.C., VRCIBRADIC, D., COSTA, P.N., MARTINS, A.R., DANTAS, L.F., GOMES, V.L.R., BERGALLO, H. G. \& ROCHA, C.F.D. 2014. Environmental parameters affecting the structure of leaf-litter frog (Amphibia: Anura) communities in tropical forests: A case study from an Atlantic Rainforest area in southeastern Brazil. Zoologia 31(2): 147-152.

SMITH, E. P \& VAN BELLE, G. 1984. Nonparametric estimation of species richness. Biometrics 40: 119-129.

SOS MATA ATLÂNTICA, INPE. 2018. Atlas dos remanescentes florestais da Mata Atlântica. Fundação SOS Mata Atlântica e Instituto Nacional de Pesquisas Espaciais (INPE), São Paulo.

TELLES, F.B.S., MILITÃO, C.M., BERGALLO, H.G. \& ROCHA, C.F.D. 2015. Invasion of the alien gecko Hemidactylus mabouia (Moureau de Jonnès, 1818) in a natural habitat at Praia do Sul Biological Reserve, Ilha Grande, RJ, Brazil. Braz. J. Biol. 75(3): 768-770.

TOFT, C.A. \& DUELLMAN, W.E. 1979. Anurans of the lower Rio Llullapichis, Amazonian Peru: A preliminary analysis of community structure. Herpetologica 35(1): 71-77.

TOZETTI, A.M., SAWAYA, R.J., MOLINA, F.B., BÉRNILS, R.S., BARBO, F.E., LEITE, J.C.M., BORGES-MARTINS, M., RECODER, R., TEIXEIRA JR., M., ARGÔLO, A.J.S., MORATO, S.A.A. \& RODRIGUES, M.T. 2017. Répteis. In: Revisões em Zoologia: Mata Attântica (E.L.A. Monteiro-Fillho \& C.E. Conte, eds.) 1. ed. Editora UFPR, Curitiba, p. 315-364.

UETZ, P., FREED, P. \& HOŠEK, J. 2019. The reptile database. Available online at: http://www.reptile-database.org (accessed on 02/10/2020).

VAN DIJK, P.P., HARDING, J. \& HAMMERSON, G.A. 2011. Trachemys scripta (errata version published in 2016). The IUCN red list of threatened species 2011: e.T22028A97429935. Available online at: https://www.iucnredlist. org/species/22028/97429935 (accessed on 02/10/2020).

VANZOLINI, P.E. 1994. On the distribution of certain South American turtles (Testudines: Testudinidae \& Chelidae). Smithson. Herpetol. Inf. Serv. 97: 1-10.

VANZOLINI, P.E. \& MYERS, C.W. 2015. The herpetological collection of Maximilian, Prince of Wied (1782-1867), with special reference to Brazilian materials. Bull. Am. Mus. Nat. Hist. 395: 1-155.

VARGAS-RAMÍREZ, M., MARAN, J. \& FRITZ, U. 2010. Red-and yellowfooted tortoises, Chelonoidis carbonaria and C. denticulata (Reptilia: Testudines: Testudinidae), in South American savannas and forests: Do their phylogeographies reflect distinct habitats? Org. Divers. Evol. 10(2): 161-172.

VERDADE, V.K. \& RODRIGUES, M.T. 2007. Taxonomic review of Allobates (Anura, Aromobatidae) from the Atlantic Forest, Brazil. J. Herpetol. 41(4): 566-580.

VRCIBRADIC, D., ROCHA, C.F.D., KIEFER, M.C., HATANO, F.H., FONTES, A.F., ALMEIDA-GOMES, M., SIQUEIRA, C.C., PONTES, J.A.L., BORGES-JR., V.N.T., GIL, L.O., KLAION, T., RUBIÃO, E.C.N. \& VAN SLUYS, M. 2011. Herpetofauna, Estação Ecológica Estadual do Paraíso, state of Rio de Janeiro, southeastern Brazil. Check List 7(6): 745-749. 
Herpetofauna from the Parque Nacional da Tijuca

WEYGOLDT, P. 1989. Changes in the composition of mountain stream frog communities in the Atlantic mountains of Brazil: Frogs as indicators of environmental deteriorations? Stud Neotrop Fauna E. 24(4): 249-255.

WHITTAKER, R.H. 1965. Dominance and diversity in land plant communities. Science 147(3655): 250-260.

WIENS, J.J., GRAHAM, C.H., MOEN, D.S., SMITH, S.A. \& REEDER, T.W. 2006. Evolutionary and ecological causes of the latitudinal diversity gradient in hylid frogs: treefrog trees unearth the roots of high tropical diversity. Am. Nat. 168(5): 579-596.

WINCK, G.R., ALMEIDA-SANTOS, M., DORIGO, T.A., TELLES, F.B. \& ROCHA, C.F.D. 2017. When invasion may not be harmful: Niche relations in a lizard assemblage. Biotropica 49(1): 117-129.
ZAHER, H., GRAZZIOTIN, F.G., CADLE, J.E., MURPHY, R.W., MOURALEITE, J.C. \& BONATTO, S.L. 2009. Molecular phylogeny of advanced snakes (Serpentes, Caenophidia) with an emphasis on South American xenodontines: A revised classification and descriptions of new taxa. Pap. Avulsos Zool. 49:115-153.

Received: $27 / 02 / 2020$

Revised: 17/03/2021

Accepted: 19/03/2021

Published online: 17/05/2021 